\title{
Republic of Kazakhstan: Financial System Stability Assessment-Update including Reports on the Observance of Standards and Codes on the following topics: Banking Supervision and Anti-Money Laundering and Combating the Financing of Terrorism
}

This update to the Financial System Stability Assessment on the Republic of Kazakhstan was prepared by a staff team of the International Monetary Fund and the World Bank as background documentation for the periodic consultation with the member country. It is based on the information available at the time it was completed on June 30, 2004. The views expressed in this document are those of the staff team and do not necessarily reflect the views of the government of the Republic of Kazakhstan or the Executive Board of the IMF.

The policy of publication of staff reports and other documents by the IMF allows for the deletion of market-sensitive information.

To assist the IMF in evaluating the publication policy, reader comments are invited and may be sent by e-mail to publicationpolicy@imf.org.

\footnotetext{
Copies of this report are available to the public from

International Monetary Fund • Publication Services

700 19th Street, N.W. • Washington, D.C. 20431

Telephone: (202) 6237430 • Telefax: (202) 6237201

E-mail: publications@imf.org• Internet: http://www.imf.org
}

Price: $\$ 15.00$ a copy

\section{International Monetary Fund Washington, D.C.}





\title{
INTERNATIONAL MONETARY FUND
}

\author{
REPUBLIC OF KAZAKHSTAN
}

\section{Financial System Stability Assessment Update}

\author{
Prepared by the Monetary and Financial Systems and the Middle East and Central Asia \\ Departments
}

\author{
Approved by Stefan Ingves and Mohsin S. Khan
}

June 30, 2004

\begin{abstract}
This Financial System Stability Assessment (FSSA) Update Report is based on work undertaken by a mission to Kazakhstan during the period February 11-25, 2004, as part of the joint World Bank-IMF Financial Sector Assessment Program (FSAP). The preliminary results of the FSAP Update were discussed with the First Deputy Prime Minister, the Governor of the National Bank of Kazakhstan, and the Chairman of the Agency of the Republic of Kazakhstan on Regulation and Supervision of Financial Markets and Financial Institutions. Comments made by the authorities are reflected in this document.

The mission comprised Tonny Lybek (Mission chief, MFD, IMF), Paula Perttunen (Deputy mission chief, World Bank), Joy Smallwood (LEG, IMF), Peter Lohmus (MCD, IMF), Gilda Fernandez (MFD, IMF), Srobona Mitra (MFD, IMF), Susan Marcus (World Bank), Cari Votava (World Bank), Michael Andrews (World Bank expert), Serap Oguz Gonulal (World Bank expert), Rama Seth (World Bank expert), and Evgeniy Volovik (Head of the International Cooperation Unit of the KFM in Russia).
\end{abstract}

The report provides an overall stability assessment for the Kazakhstani financial system. Reports on the observance of standards and codes on banking supervision and on anti-money laundering and combating financing of terrorism are attached as Appendices II and III.

Since the 2000 FSAP, Kazakhstan has made impressive improvements in its financial sector legislation, and has revamped its institutional structure for financial sector oversight. The financial sector, which is dominated by banks, has been one of the fastest growing sectors of the economy. This has been facilitated by a favorable macroeconomic environment helped by a cautious fiscal stance, increasing oil revenue, as well as a commitment to ambitious financial sector reforms. While significant financial sector legislative reforms have been adopted since 2000 , the implementation is lagging in some areas, such as consolidated supervision. Stress tests of the banking system reveal potential weaknesses, although reported prudential indicators are in a comfortable range. Ceilings on "excessive interest rates" of deposits insured by the Deposit Insurance Fund are administrative steps that cannot substitute for effective banking supervision. While external public debt is declining, private external debt is increasing. Existing Kazakhstani legislation and enforcement powers to combat money laundering and financing of terrorism do not sufficiently address the exposure to these risks, but improvements have been initiated.

The main authors of this report are T. Lybek, P. Lohmus, J. Smallwood, G. Fernandez, and S. Mitra.

FSAPs are designed to assess the stability of the financial system as a whole and not that of individual institutions. They have been developed to help countries identify and remedy weaknesses in their financial sector structure, thereby enhancing resilience to macroeconomic shocks and cross-border contagions. FSAPs do not cover risks specific to individual institutions such as asset quality, operational or legal risks or fraud. 


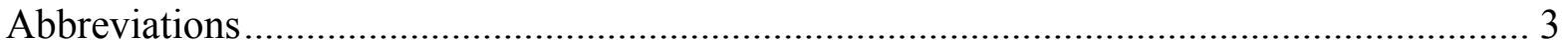

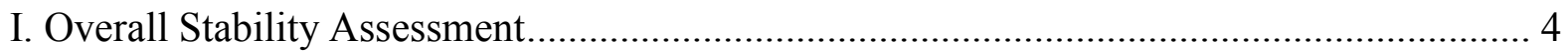

II. Macroeconomic and Financial Sector Developments since the 2000 FSAP .................... 6

III. Vulnerabilities and Development Opportunities in the Financial Sector ...................... 13

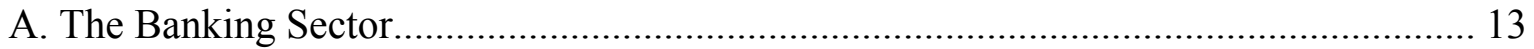

B. Nonbank Financial Institutions ....................................................................... 17

IV. Assessments and Updates of Selected Standards and Codes ..................................... 18

A. Reassessment: Basel Core Principles for Effective Banking Supervision.................... 18

B. Update: IOSCO Principles on Securities Regulation............................................... 19

C. Update: IAIS Insurance Principles .......................................................................... 19

D. Update: Core Principles for Systemically Important Payment Systems...................... 19

E. Update: Practices on Transparency in Monetary and Financial Policies ..................... 20

F. Assessment: Prevention of Money Laundering and Combating Financing of

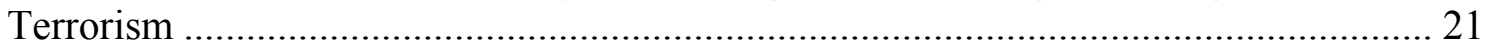

Box

1. Main Recommendations of the 2004 FSAP Update Mission .......................................6

Tables

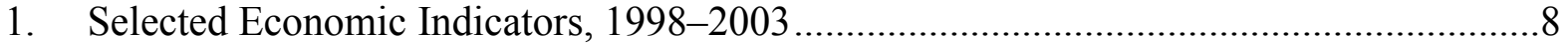

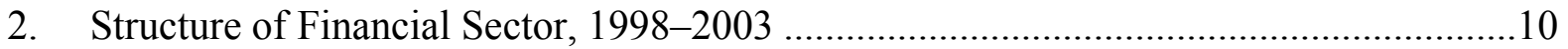

3. Selected Prudential Indicators of the Banking Sector, 1998-2003 ...............................14

Figure

1. Capital Adequacy Ratio Adjusted for an Increase in Classified Loans, January 1, 2004 .....

Appendices

I. Progress since the 2000 FSAP Mission....

II. Report on the Observance of Standards and Codes - Summary Assessment of Banking Supervision

III. Report on the Observance of Standards and Codes-Summary Assessment of AML/CFT 


\section{AbBreviations}

$\begin{array}{ll}\text { AML } & \text { Anti-Money Laundering } \\ \text { BCP } & \text { Basel Core Principles for Effective Banking Supervision } \\ \text { CAR } & \text { Capital Adequacy Ratio } \\ \text { CFT } & \text { Combating the Financing of Terrorism } \\ \text { CIS } & \text { Commonwealth of Independent States } \\ \text { DIF } & \text { Deposit Insurance Fund } \\ \text { EU } & \text { European Union } \\ \text { FIU } & \text { Financial Intelligence Unit } \\ \text { FSA } & \text { Agency of the Republic of Kazakhstan on Regulation and Supervision } \\ & \text { of Financial Markets and Financial Institutions } \\ \text { FT } & \text { Financing Terrorism } \\ \text { GDP } & \text { Gross Domestic Product } \\ \text { IAIS } & \text { International Association of Insurance Supervisors } \\ \text { IAS } & \text { International Accounting Standards } \\ \text { IFRS } & \text { International Financial Reporting Standards (formerly IAS) } \\ \text { IOSCO } & \text { International Organization of Securities Commissions } \\ \text { ISA } & \text { International Standards on Auditing } \\ \text { ISMT } & \text { Interbank System of Money Transfers } \\ \text { JSC } & \text { Joint Stock Company } \\ \text { KMC } & \text { Kazakhstan Mortgage Company } \\ \text { T } & \text { Tenge (local currency unit) } \\ \text { ML } & \text { Money Laundering } \\ \text { NBK } & \text { National Bank of Kazakhstan } \\ \text { NFRK } & \text { National Fund of the Republic of Kazakhstan } \\ \text { ROSC } & \text { Report on Observance of Standards and Codes } \\ \text { SDDS } & \text { Special Data Dissemination Standard } \\ \text { SMA } & \text { Securities Market Act } \\ \text { SRP } & \text { System of Retail Payments }\end{array}$




\section{Overall Stability Assessment}

1. The financial sector, which is dominated by private commercial banks, has been one of the fastest growing sectors in Kazakhstan. This has been facilitated by a favorable macroeconomic environment characterized by early structural reforms, a cautious fiscal stance, increasing oil revenue, and a commitment to ambitious financial sector reforms. Since the 2000 FSAP, Kazakhstan has made impressive improvements in several aspects of financial sector legislation, and has revamped its institutional structure for financial sector oversight. ${ }^{1}$ Effective implementation of these commendable measures is crucial for achieving the intended objectives.

\section{The reform agenda is ambitious and anticipates even more far-reaching} developments. The National Bank of Kazakhstan (NBK) has announced the transition to the principles for inflation targeting and full liberalization of capital account transactions by 2007. The financial supervisory authority (FSA) is contemplating adopting EU standards. This creates additional challenges for the financial sector, the FSA, and the NBK. Preconditions for full capital account liberalization include robust financial institutions and markets, combined with adequate monitoring of market risks. The developing financial sector is likely to also change the monetary transmission mechanism. Accordingly, the NBK will have to continuously monitor a wide range of indicators, including asset prices, to avoid slippages in maintaining domestic price stability.

3. Although the capital adequacy ratio of the banking system seems comfortable, stress testing reveals several potential vulnerabilities, including credit risk and reliance on unbalanced wholesale funding. Some of the largest banks are barely above the minimum capital adequacy requirement. The share of classified assets remains substantial and has been increasing in spite of high real growth. Although this is in part due to new stricter classification requirements introduced in 2003, rapid credit growth also appears to have contributed to the deteriorating loan quality. Continued diligence is warranted, including on related-party lending and aggregated large exposures, which can best be ensured by timely on-site inspections. Prudential indicators for liquidity risk suggest that the banking system is liquid on aggregate, but reported liquidity ratios do not fully reveal the extent of some banks' reliance on potentially volatile wholesale funding. Although the limit on the aggregate exchange rate risk errs on the high side, limits on individual currencies help contain this risk. Banks still have some indirect exposure, although this risk is currently mitigated by appreciation expectations.

\section{The authorities should resist pressures for administrative measures to address} specific policy concerns. Improving stability in the financial sector and increasing efficiency

\footnotetext{
${ }^{1}$ The 2000 pilot FSAP mission took place during the period February 21 to March 10, and the FSSA was issued on November 27, 2000. Appendix I shows the main recommendations of the 2000 FSAP. The Monetary and Financial Systems Department (MFD) has since provided technical assistance on integrated supervision, capital account liberalization, and payment systems.
} 
has brought some benefit to the real sector through lower loan rates and interest margins. However, with real sector development still lagging that of the financial sector, there are pressures for administrative measures to force down interest rates. A case in point includes the introduction of ceilings on "excessive deposit rates" by the Deposit Insurance Fund. Such interest ceilings create risks and could hide severe problems in individual banks. If some banks offer and charge relatively high interest rates, it may be an indication of lack of competition or of business practices that warrant closer monitoring. Banks offering relatively high deposit rates should be effectively supervised, whereupon these interest ceilings should be removed.

5. Private capital market development will depend on-in addition to a continued favorable macroeconomic environment-more transparent corporate governance and appropriate, non-intrusive oversight from regulators. The low level of competition in some key economic sectors and the influential financial-industrial groupings limit the number of potential issuers in the market. The mixed legacy of the first wave of privatizations, some enterprises' concerns regarding increased transparency, and the cost of listing may slow financial deepening. The issuance of corporate bonds will be facilitated by the government issuing larger and less frequent tranches of securities to become benchmarks.

6. The establishment of Kazakhstan Mortgage Company (KMC) has helped financial sector development, and its privatization should be encouraged. While an important step for encouraging home ownership through the offering of affordable mortgages, it has also helped create a new financial instrument, securitized mortgage bonds. The program also faces some risks. If the market grows too fast, facilitated by demand from pension funds, the real estate markets in the largest population centers could overheat and cause a real estate bubble. It is encouraging that the authorities are considering to better monitor real estate prices in more densely populated areas. Privatization of the $\mathrm{KMC}$ would allow the market place to build on this generally sound initiative.

7. The authorities' intention to further strengthen consolidated supervision, move toward a more risk-based supervisory approach, and implement EU standards by 2007 is commendable. Consolidated supervision is becoming increasingly important as banking groups have broadened their activities. Consolidated supervision has been facilitated by unifying the various regulators into one body. Risk management regulations for banks and investment regulations for insurance companies have recently been issued. This is a good step in moving from a mainly rule-based approach with frequent reporting requirements to a more risk-based approach. EU directives can serve as useful benchmarks, but they are also time-consuming to implement, which should be done gradually. Before even considering adopting the Basel II Capital Accord, effective consolidated supervision and capital requirements for market risks included in the current Accord should be implemented.

\section{Existing Kazakhstani legislation and enforcement powers to combat money} laundering and the financing of terrorism need strengthening. Kazakhstan's location tempts organized criminals and oil swaps offer a potential for abuse. Sound anti-money laundering (AML) and combating the financing of terrorism (CFT) policies, with appropriate 
checks and balances to prevent their abuse, would send an important signal regarding the authorities' commitment to ensure an even playing field. Box 1 summarizes the main recommendations of the FSAP update.

Box 1. Kazakhstan: Main Recommendations of the 2004 FSAP Update Mission

\section{Supervision}

1. Implement consolidated supervision. Follow through on the initial steps already taken, including ensuring adequate resources to conduct the scheduled number of comprehensive on-site inspections of commercial banks.

2. Implement the recently issued regulation on risk-management on banks, thus moving from a primarily rule-based approach toward a more risk-based approach.

3. Stipulate in law that high level officials at the NBK and the FSA can be removed only for cause with the reasons made public.

4. Reassess the frequency and detail of reporting requirements for market participants.

5. Provide continuous training, including upgrading of skills, particularly for nonbank supervisors to meet the challenges of the newly adopted legislation.

\section{Banking}

1. Take prompt supervisory action, if required, to deal with banks paying excessive interest rates. Then the limits on excessive interest rates introduced by the Deposit Insurance Fund can be removed.

2. Increase focus on liquidity risk of individual institutions. Some banks rely on potentially volatile wholesale funding.

3. Consideration should be given to introducing capital requirements for market risks.

Capital markets

1. Structure government debt issuance to be more conducive for debt market development.

Insurance

1. Establish a reliable database to determine reserve requirements and tariffs for existing products.

2. Before introducing additional compulsory insurance products, ensure preconditions to determine appropriate reserve requirements and tariffs are in place.

\section{Pension funds}

1. Review the regulatory framework for hidden incentives that do not promote prudent investment strategies appropriate for social safety net assets.

Corporate governance

1. Undergo a Corporate Governance Report on Observance of Standards and Codes (ROSC) assessment to evaluate the implementation of existing voluntary governance guidelines.

Anti-money laundering and combating financing of terrorism

1. Bring the criminalization of money laundering and the financing of terrorism in line with international standards.

2. Enact a legal framework consistent with international standards, including appropriate checks and balances preventing abuse, as well as a financial intelligence unit (FIU).

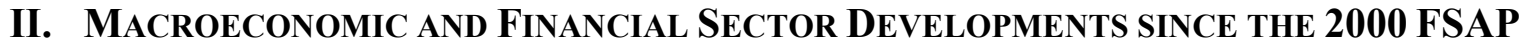

\section{The 2000 FSAP found that the Kazakhstani financial system had escaped serious repercussions from the Russian crisis in 1998, but that it was operating in an}


environment with underdeveloped supporting institutions and infrastructure. Notably, supervisory authorities had limited information about the close links among large business groups, banks, and government officials. Forbearance and other supervisory weaknesses were identified. The largest banks were found to be subject to credit risk and exchange rate risk; two of them had sizable exposures to the oil industry. Credit risk was substantial due to the high level of nonperforming loans and significant exposures to large corporations facing financial difficulties. Banks were also exposed to indirect exchange rate risk, that is, some borrowers had loans denominated in foreign currencies without having a sufficient income stream denominated in foreign currencies to service these loans.

\section{Since 2000, the favorable macroeconomic environment has been conducive to}

financial sector development. Facilitated by early structural reforms, strong oil revenues, and prudent macroeconomic management, real GDP growth averaged 101/2 percent per year during 2000-03 (Table 1). Unemployment has declined and inflation has remained below 7 percent. The banking system has continued to grow at a rapid pace, while the number of banks has declined. As an indication of financial deepening, the broad money stock (M3) rose from 15 percent of GDP at end-2000 to 22 percent of GDP at end-2003 (291/2 percent of non-oil GDP). The share of deposits and loans denominated in local currency has increased since 2001. Private pension funds are accumulating substantial resources, which amounted to $81 / 2$ percent of GDP at end-2003.

11. Macroeconomic risks appear moderate at present. Hydrocarbon exports account for more than half of total exports. Both the authorities' and Fund staff's estimates suggest that a significant decline of oil prices would initially have a moderate effect, since it would be cushioned by the National Fund of the Republic of Kazakhstan (NFRK, US\$3.6 billion at end-2003) and production is expected to increase over time. Furthermore, gross international reserves reached almost US\$5 billion at end-2003, exceeding estimated short-term debt (US\$3.8 billion). Nevertheless, the level of private external debt (65 percent of GDP) remains high, has grown rapidly, and only part of it may have been used to finance the tradables sector. A large share is intra-company loans (401/2 percent of GDP).

\section{Exports and capital inflows have continued to grow, creating inflationary}

pressures. Under the managed floating exchange rate system, inflows have created appreciation and inflation pressures, which in part have been neutralized by the NFRK, in part absorbed by increased money demand, and in part sterilized by the NBK. Although the growing deposit base reflects confidence in monetary policy and the banking sector, rapid credit expansion and high levels of classified loans warrant caution.

\section{Major structural and legislative changes have occurred since the 2000 FSAP.} Effective January 1, 2004, supervision of the financial sector including its supervisory staff was moved from the NBK to the new Agency of the Republic of Kazakhstan on Regulation and Supervision of Financial Markets and Financial Institutions (FSA). The new agency is accountable to the president. For the foreseeable future, it will remain on the premises of, and be funded by the NBK. This should help prevent funding being used to exert undue influence on the FSA. A detailed agreement on cooperation has been signed by the FSA and the NBK, 
Table 1. Kazakhstan: Selected Economic Indicators, 1998-2003

\begin{tabular}{|c|c|c|c|c|c|c|}
\hline & 1998 & 1999 & 2000 & 2001 & 2002 & $\begin{array}{r}2003 \\
\text { Prelim. }\end{array}$ \\
\hline Real GDP growth (percent) & -1.9 & 2.7 & 9.8 & 13.5 & 9.8 & 9.2 \\
\hline Growth of consumer prices (CPI, percent) & 1.9 & 17.8 & 9.8 & 6.4 & 6.6 & 6.8 \\
\hline Unemployment (percent) & 13.1 & 13.5 & 12.8 & 10.4 & 9.3 & 9.0 \\
\hline General government balance (cash basis, percent of GDP) & -7.7 & -5.0 & -0.8 & 2.6 & 1.4 & 3.0 \\
\hline General government non-oil balance (cash basis, percent of GDP) & $\ldots$ & -6.0 & -4.1 & -3.1 & -3.0 & -3.2 \\
\hline National Fund of the Republic of Kazakhstan (percent of GDP) & $\ldots$ & $\ldots$ & $\ldots$ & 5.6 & 7.9 & 12.3 \\
\hline Public debt (percent of GDP) & 22.5 & 29.7 & 25.6 & 20.9 & 17.6 & 15.0 \\
\hline Domestic public debt (percent of GDP) & 4.6 & 5.8 & 4.1 & 3.7 & 3.3 & 2.9 \\
\hline External public debt (percent of GDP) & 17.9 & 23.9 & 21.5 & 17.2 & 14.2 & 12.2 \\
\hline Current account balance (percent of GDP) & -5.4 & -0.1 & 4.2 & -4.0 & -3.5 & -0.2 \\
\hline External debt (percent of GDP) & 44.8 & 71.3 & 69.3 & 68.5 & 74.1 & 76.9 \\
\hline Gross official reserves (millions of US\$) & 1,964 & 2,003 & 2,096 & 2,508 & 3,136 & 4,961 \\
\hline National Fund of the Republic of Kazakhstan (millions of US\$) & $\ldots$ & $\ldots$ & $\ldots$ & 1,270 & 1,917 & 3,603 \\
\hline Short-term external debt (million US\$) & 2,321 & 1,805 & 1,021 & 1,366 & 2,360 & 3,771 \\
\hline Gross official reserves (month of imports) & 3.0 & 3.6 & 2.8 & 2.9 & 3.3 & 4.5 \\
\hline Exchange rate average (period average, tenge per U.S. dollar) & 78.6 & 120.1 & 142.1 & 146.9 & 153.5 & 149.7 \\
\hline Exchange rate average (period average, tenge per Russian ruble) & 10.4 & 4.8 & 5.1 & 5.0 & 4.9 & 4.9 \\
\hline Change in real exchange rate (REER) 1/ & 21.0 & -26.8 & -0.6 & -1.5 & -5.0 & -2.4 \\
\hline Broad money growth (M3, Dec./Dec, percent) & -14.1 & 84.4 & 45.6 & 42.8 & 34.1 & 26.8 \\
\hline Financial deepening I (M3 in percent of GDP) & 8.6 & 13.6 & 15.4 & 17.5 & 20.3 & 21.8 \\
\hline Financial deepening II (M3 in percent of non-oil GDP) & 9.2 & 15.7 & 21.4 & 23.1 & 26.4 & 29.5 \\
\hline Currency in circulation (percent of GDP) & 4.0 & 5.1 & 4.1 & 4.0 & 4.3 & 5.4 \\
\hline Turnover of payment systems (times GDP) & 1.9 & 2.1 & 2.7 & 3.2 & 4.1 & 5.1 \\
\hline Refinance rate, percent end of period & 25.0 & 18.0 & 14.0 & 9.0 & 7.5 & 7.0 \\
\hline 3-month treasury bill rate (year-end) & 25.6 & 16.6 & 7.0 & 5.2 & 5.3 & 6.0 \\
\hline \multicolumn{7}{|l|}{ Foreign currency debt rating: } \\
\hline Moody's & $\mathrm{Ba} 3$ & B1 & B1 & $\mathrm{Ba} 2$ & $\mathrm{Baa} 3$ & Baa3 \\
\hline Standard and Poor's 2/ & $\mathrm{B}+$ & $\mathrm{B}+$ & BB- & BB & $\mathrm{BB}+$ & $\mathrm{BB}+$ \\
\hline \multicolumn{7}{|l|}{ Memorandum item: } \\
\hline Nominal GDP (billions of tenge) & 1,733 & 2,016 & 2,600 & 3,251 & 3,776 & 4,450 \\
\hline
\end{tabular}

Sources: National Bank of Kazakhstan and Fund staff estimates.

1/ A negative sign indicates an appreciation.

2/ In May 2004, Standard \& Poor's raised Kazakhstan's foreign currency debt rating to investment grade (BBB-) citing increased government revenue from oil exports. 
which addresses the provision of premises and services for the new agency, and outlines specific information-sharing measures. The FSA chairman's term is not explicitly specified. Ideally, it should be longer than that of the body with the predominant role in appointing the chairman. Although Article 26 of the Law on Public Service stipulates that misdeeds are grounds for dismissal, the chairman of the FSA and the governor of the NBK are not protected against arbitrary dismissal during their term. These are major deficiencies in ensuring the autonomy of both the NBK and the FSA.

14. The financial system, which is dominated by private commercial banks, has been one of the most rapidly growing sectors of the economy. While the number of banks has declined, the total assets of the banking system have increased to almost 38 percent of GDP (Table 2). The three largest banks hold about 65 percent of deposits by individuals. About half of the banks have some foreign participation. Halyk Savings Bank was privatized in October 2001 and Eximbank in February 2004. However, a new state-owned bank (Zhilstroi Bank) was established in 2003 to finance housing construction. ${ }^{2}$ At some stage, consideration should be given to its privatization. Increasing access to foreign financial markets will open the domestic market to more competition.

15. In spite of robust economic growth, the proportion of banks' classified loans (doubtful and loss) increased from almost 29 percent at end-2002 to 39 percent of total loans at end-2003, while classified assets and contingent liabilities increased from 19.2 percent of total assets to 29.8 percent during the same period. The introduction of a stricter asset classification and provisioning methodology in early 2003, contributed to the increase. ${ }^{3}$ Classified loans not on time increased from 12.2 percent of total loans in March to 13.1 percent in December 2003. At end-2003, loan loss provisions amounted to 6.2 percent of loans. Rapid credit growth and diversification of lending into new riskier businesses may also have contributed to the increase. The authorities also explain the increase by overprovisioning to smooth income. ${ }^{4}$ Problem loans often increase after a period with aggressive credit growth, particularly if banks lend to new types of businesses with which they are not familiar. Macroeconomic shocks may also adversely affect the quality of the loan portfolio.

\footnotetext{
${ }^{2}$ The Development Bank, which is also state-owned, is not a commercial bank and is not included in these figures. It is governed by separate legislation, does not accept deposits from the public, but reports to the FSA.

${ }^{3}$ Data to estimate the precise impact were not available, but both the FSA and banks were of the opinion that the new policy is stricter. The new formula explicitly considers factors such as the financial condition of the borrower and the quality of the collateral held in addition to days in arrears. This approach is intended to lead to a more realistic estimate of the current realizable value of assets. Each asset is to be evaluated using a formula that sums values assigned to various characteristics of the investment, with positive values assigned for adverse characteristics, and negative values assigned for things that would mitigate potential losses.

${ }^{4}$ The mission recommended that specific provisions be deductible from income, since this practice would not materially affect tax revenues over time, since over-provisioning in one period would lead to increased taxable income in future periods when the excess provisions are reversed.
} 
Table 2. Kazakhstan: Structure of Financial Sector, 1998-2003

\begin{tabular}{|c|c|c|c|c|c|c|}
\hline & 1998 & 1999 & 2000 & 2001 & 2002 & $\begin{array}{l}20031 / \\
\text { Prelim. }\end{array}$ \\
\hline & \multicolumn{6}{|c|}{ (Numbers unless otherwise indicated) } \\
\hline Banks 1/ & 71 & 55 & 48 & 44 & 38 & 35 \\
\hline Of which: fully state-owned $1 /$ & 1 & 1 & 1 & 1 & -- & 2 \\
\hline Of which: with foreign participation $2 /$ & 23 & 22 & 16 & 16 & 17 & 16 \\
\hline Bank branches & 459 & 426 & 418 & 400 & 368 & 355 \\
\hline Cash divisions of commercial banks & 1,282 & 1,065 & 964 & 1,020 & 1,020 & 1,286 \\
\hline Assets of commercial banks (percent of GDP) & 11.3 & 16.9 & 20.3 & 25.1 & 30.6 & 37.7 \\
\hline $\begin{array}{l}\text { Nonbank institutions licensed to carry out certain banking } \\
\text { operations } 3 /\end{array}$ & 29 & 47 & 53 & 43 & 44 & 49 \\
\hline $\begin{array}{l}\text { Cumulative assets financial institutions performing certain } \\
\text { banking operations } 3 / \text { (percent of GDP) }\end{array}$ & 3.8 & 4.2 & 4.9 & 2.3 & 1.9 & 2.1 \\
\hline Private pension funds & 13 & 16 & 15 & 14 & 16 & 16 \\
\hline Assets managed by private pension funds (percent of GDP) & 1.4 & 3.2 & 4.3 & 5.6 & 7.2 & 8.4 \\
\hline Insurance companies & 72 & 70 & 42 & 36 & 34 & 32 \\
\hline Insurance companies with foreign participation & 9 & 7 & 4 & 5 & 3 & 6 \\
\hline Life insurance companies & 3 & 3 & 1 & 1 & 1 & 1 \\
\hline Gross premiums of insurance companies (percent of GDP) & $\ldots$ & $\ldots$ & 0.3 & 0.4 & 0.6 & 0.6 \\
\hline Credit associations & 2 & 5 & 8 & 19 & 29 & 52 \\
\hline Licensed pawn shops & 36 & 36 & 42 & 45 & 52 & 66 \\
\hline Capital markets, capitalization (percent of GDP) 4/ & 30.0 & 28.8 & 29.7 & 40.7 & 48.9 & 51.5 \\
\hline Securities issued by the Ministry of Finance (percent of GDP) & 4.3 & 5.3 & 2.5 & 11.1 & 2.2 & 3.9 \\
\hline NBK notes (percent of GDP) & 0.7 & 0.3 & 5.2 & 7.9 & 2.0 & 4.5 \\
\hline Securities issued by local governments (percent of GDP) & $\ldots$ & 0.1 & -- & 0.2 & 0.1 & 0.2 \\
\hline Corporate bonds (percent of GDP) & $\ldots$ & 0.2 & 1.0 & 0.9 & 2.5 & 4.1 \\
\hline Equities (percent of GDP) 4/ & 25.1 & 23.0 & 21.0 & 20.6 & 42.0 & 38.4 \\
\hline Mortgage-backed bonds issued by the KMC (percent of GDP) & $\ldots$ & $\ldots$ & $\ldots$ & -- & 0.1 & 0.3 \\
\hline
\end{tabular}

Sources: National Bank of Kazakhstan and Fund staff estimates.

1/ These numbers do not include the Development Bank. Halyk Savings Bank was fully privatized in October 2001. Zhilstroi Bank is a state-owned bank providing housing financing was licensed in mid-2003. Eximbank was privatized in February 2004.

2/ The number of representative offices of foreign banks has fluctuated between 12 and 17 during 1998 to 2002, but increased from 14 to 19 during 2003. The number of representative office of Kazakhstani banks has increased from 3 at the beginning of 2000 to 19 at the beginning of 2004 .

3/ Including the Kazakhstan Mortgage Company.

4/ There is an unexplained break in the data between 2001 and 2002. The Securities Markets Act reduced the number of companies significantly in 2003. Companies with low capital previously categorized as joint stock companies became limited liability companies. 
While the new stricter loan classification and provisioning policy is an important step to preempt potential problems in light of rapid credit growth, continued diligence is warranted. ${ }^{5}$

16. The NBK functions as lender of last resort. It extends such loans on a case-by-case basis, thus using constructive ambiguity, like many other central banks, to avoid moral hazard. In 2001, however, the NBK in effect covered all pensions and depositors of a failed bank by extending a loan to a then state-owned bank that paid the depositors of the failing bank. A bank's commitment to address underlying problems should be a precondition for a lender-of-last-resort-loan.

\section{Effective January 1, 2004, the legal framework for liquidation of banks and} other financial institutions has changed significantly. With a view to avoid time consuming liquidation procedures during which the recovery rates deteriorate, the FSA has been given more authority to control and monitor the liquidator. A representative from the Deposit Insurance Fund can become a member of the liquidation committee. To ensure checks and balances, the liquidation request and the report of the liquidation committee must still be approved by the court. The new approach appears to be an important improvement.

18. A deposit insurance scheme was established in 1999 but became compulsory only on January 1, 2004 for banks accepting household deposits. The Deposit Insurance Fund (DIF) is fully owned by the NBK. Deposits of individuals are insured up to T 400,000 (US\$2,900) per bank, with deposits from large shareholders and parties related to the management excluded. Currently, it has accumulated funds to cover insured deposits of no more than two to three of the smaller banks. The DIF targets 5 percent of insured liabilities. Currently, premiums are set at 0.25 percent of insured deposits for newly insured banks and 0.16 percent for older banks. Risk-adjusted deposit insurance premiums seem premature in the current environment. In principle, the use of risk-based premiums is a sound approach, but in practice it is difficult to determine fair premiums. At this stage, it is also important to have a simple and transparent framework. ${ }^{6}$

19. Weak banks should be dealt with through supervisory measures instead of using caps on deposit rates established by the Deposit Insurance Fund. A limit on "excessive" interest rates on insured deposits can easily be circumvented and reduces transparency. Instead, banks that offer excessive interest rates - as determined by the DIF - to attract deposits or lend to borrowers that are willing to pay very high interest rates should attract the attention of the FSA and trigger inspections.

\footnotetext{
${ }^{5}$ A survey of credit booms in emerging markets during the period 1970 to 2002 found that they pose significant risks because they are typically followed by sharp economic downturns and financial crises (chapter IV in World Economic Outlook, (International Monetary Fund), April 2004, Washington D.C.).

${ }^{6}$ For a discussion of risk-adjusted deposit insurance premiums, see Deposit Insurance: Actual and Good Practices, IMF Occasional Paper No. 197 (International Monetary Fund), 2000, Washington, D.C., page 18.
} 
20. Kazakhstan was one of the first Commonwealth of Independent States (CIS) economies to initiate a pension reform and pension funds had accumulated some US\$2.5 billion (almost $81 / 2$ percent of GDP) on 6.4 million accounts as of January 1 , 2004. ${ }^{7}$ Sixteen private pension funds are in operation, investing mainly in government securities (53 percent of their portfolio), corporate bonds ( 24 percent), foreign investments (10 percent), and bank deposits ( 7 percent). Equity investments are permitted but remain relatively modest due to lack of supply.

\section{The recently amended Law on Joint Stock Companies (JSC) removes the} provision of "closed" joint stock companies and increases the amount of required chartered capital. ${ }^{8}$ This Law also requires that shares be maintained by an independent, licensed shares registry. It also improves the protection of minority shareholders.

22. Capital markets are developing. Trading on the Kazakhstan Stock Exchange is concentrated in foreign exchange, repurchase agreements, and government debt instruments, although the capitalization of the corporate bond market has grown to $\mathrm{T} 182 \frac{1}{2}$ billion (US\$1.2 billion, 75 emissions) since its introduction in late 1999. Mortgage-backed bonds were introduced in 2002 - and since then more than T 14 1/2 billion have been issued (five emissions). The class of institutional investors continues to consist largely of pension funds thereby keeping a fairly unified demand from investors.

\section{The new Securities Market Act (SMA) enacted in 2003 is an important} improvement. It provides a clear and consistent regulatory framework, strengthens enforcement powers, provides for the authority to institute sanctions, promotes transparency, prohibits manipulation and other unfair trading practices, provides clear objectives, functions, responsibilities, powers and authority for self-regulatory organizations, and increases capital requirements for the central securities depositary.

24. The insurance industry is at a nascent stage but growing. As of January 2004, 34 insurance companies were licensed, of which two are life insurance companies. In 2003, gross premiums amounted to T 28 billion (0.6 percent of GDP), of which more than 98 percent was for non-life business. In 2002, the penetration ratio was only 0.66 percent of the population. ${ }^{9}$ Low per-capita income and a general lack of understanding among the population of the potential benefits of insurance contribute to the low levels of insurance penetration. The influence of foreign insurers in Kazakhstan is limited, although reinsurance is internationalized. Long-standing connections with Russia, a need to spread risks given the size of Kazakhstani companies, and a statutory limit on retention rates have permitted a substantial percentage of the business to be reinsured in Russia. The government is

\footnotetext{
${ }^{7}$ At end-2003, household deposits with commercial banks amounted to 61/2 percent of GDP.

${ }^{8}$ Closed JSCs were not subject to detailed public disclosure requirements.

${ }^{9}$ This is well below, for instance, Russia (2.8 percent), Ukraine (2.0 percent), Latvia (1.9 percent), and Turkey (1.3 percent).
} 
supporting the development of the insurance market through introduction of compulsory insurance in a number of areas, such as third-party liability for vehicle owners and operators, private notaries, auditors and audit companies, as well as tourism operators.

\section{VULNERABILITIES AND DEVELOPMENT OPPORTUNITIES IN THE FinANCIAL SECTOR}

\section{In Kazakhstan's bank-dominated financial sector, rapid credit expansion} warrants caution. While not of the same magnitude, the rapid increase in assets in pension funds and the absence of a deep and broad financial market to absorb these resources also require attention. There are substantial cross-relationships between financial institutions and influential groupings having holdings in both the financial and real sectors. Commercial banks can engage in a wide range of financial activities. This has contributed to the emergence of financial-industrial groups, several with non-transparent ownership structures, which heighten concerns about the extent of related party lending and large exposures of the banking sector. However, exemptions from prudential limits are reportedly no longer granted and progress in monitoring such exposures has been made since the 2000 FSAP.

\section{A. The Banking Sector}

26. The growing bank deposit base reflects confidence in monetary policy and the banking sector. In 2003, broad money (M3) continued to increase by almost 27 percent. Profitability of the commercial banks, according to unaudited financial statements, remained constant (1.96 percent of total assets in 2002 and 1.98 percent of total assets in 2003, Table 3), while banks were making larger provisions. In 2003, each of the ten largest banks reported profits. The capital adequacy ratio (CAR), which does not include capital requirements for market risks but is otherwise broadly consistent with the Basel Capital Accord, declined from 17.2 percent at end 2002 to 16.9 percent at end-2003 (preliminary). On aggregate, prudential ratios are within comfortable ranges, though several of the larger banks are close to the minimum CAR of 12 percent. Furthermore, some of them have significant proportions of classified assets, and some rely heavily on unbalanced wholesale funding.

27. It is encouraging that the FSA has taken the first initial steps toward introducing sensitivity analysis. These efforts should be intensified and cover market risks, which are likely to grow. Important next steps would be to identify certain shocks, develop the offsite reporting system to calculate the impact of such shocks, and try to estimate the relationships between levels or changes in classified assets with selected macroeconomic indicators. This will, however, be difficult in a dynamic economy.

28. Credit risk remains large. The magnitude of credit risk can be illustrated by estimating the impact on the CAR of an increase in classified loans. If such an increase had to be fully provisioned from equity capital, a 15 percent increase in classified loans wouldall other things being equal-bring the banking system's CAR down to the minimum 
Table 3. Kazakhstan: Selected Prudential Indicators of the Banking Sector, 1998-2003

\begin{tabular}{|c|c|c|c|c|c|c|}
\hline & 1998 & 1999 & 2000 & 2001 & 2002 & $\begin{array}{r}2003 \\
\text { Prelim. }\end{array}$ \\
\hline Capital adequacy ratio (K2, percent) & 29.5 & 27.6 & 25.7 & 18.6 & 17.2 & 16.9 \\
\hline Tier I capital (K1, percent of risk-weighted assets) & $\ldots$ & $\ldots$ & 18.9 & 13.3 & 10.6 & 10.5 \\
\hline Tier I capital (percent of total assets) & $\ldots$ & $\ldots$ & 14.0 & 11.0 & 9.0 & 9.0 \\
\hline Growth in banks' total assets & $\ldots$ & 74.2 & 54.8 & 54.7 & 40.2 & 46.5 \\
\hline Off-balance sheet items (percent of total assets) & 71.3 & 45.6 & 43.5 & 53.4 & 56.8 & 60.8 \\
\hline Growth in banks' loans (percent) & 30.3 & 59.3 & 85.7 & 77.3 & 37.3 & 45.5 \\
\hline Growth of claims on private non-financial institutions (percent) & 29.9 & 60.3 & 86.0 & 75.5 & 33.7 & 39.5 \\
\hline Growth of claims on households during period (percent) & 38.0 & 43.8 & 78.1 & 110.4 & 90.2 & 107.8 \\
\hline Classified assets to total assets (percent) $1 /$ & 20.7 & 22.4 & 12.7 & 19.8 & 19.2 & 29.8 \\
\hline Classified loans to total loans (percent) $1 /$ & 36.4 & 44.7 & 23.2 & 31.0 & 28.7 & 38.9 \\
\hline Nonperforming loans (percent of total loans) $2 /$ & $\ldots$ & $\ldots$ & $\ldots$ & $\ldots$ & 12.2 & 13.1 \\
\hline Loans classified as loss ("unattended," percent of total loans) 1/ & 4.7 & 5.5 & 2.1 & 2.1 & 2.0 & 2.1 \\
\hline Loan loss provisions (percent of total sum of loans) $1 /$ & 8.2 & 9.5 & 4.5 & 4.7 & 5.5 & 6.2 \\
\hline Net foreign assets (percent of total assets) & 1.7 & 5.1 & 0.3 & 6.6 & 6.1 & 1.7 \\
\hline Net open position in foreign exchange (percent of Tier I+II) & $\ldots$ & $\ldots$ & 19.4 & 18.9 & 7.7 & -1.2 \\
\hline Share of deposits denominated in foreign exchange (percent) $3 /$ & 37.0 & 47.8 & 50.9 & 60.9 & 60.0 & 47.1 \\
\hline Share of loans denominated in foreign exchange (percent) $3 /$ & 43.2 & 53.9 & 51.0 & 71.2 & 68.5 & 55.5 \\
\hline Securities (percent of total assets) 4/ & 12.7 & 13.0 & 9.7 & 16.6 & 17.0 & 19.6 \\
\hline Liquidity ratio (K4) & 0.69 & 0.95 & 0.98 & 0.83 & 0.78 & 0.90 \\
\hline Loan to deposit ratio (percent) & 117.1 & 87.3 & 95.1 & 110.1 & 111.5 & 133.8 \\
\hline Loan to deposit ratio denominated in foreign exchange (percent) 3/ & 136.8 & 98.7 & 95.3 & 130.8 & 127.3 & 157.6 \\
\hline Return on assets, before tax (percent of assets end of period) & $\ldots$ & $\ldots$ & 1.5 & 0.9 & 2.0 & 2.0 \\
\hline Return on equity, before tax (percent of equity) & $\ldots$ & $\ldots$ & 7.6 & 5.4 & 13.8 & 14.6 \\
\hline
\end{tabular}

Sources: National Bank of Kazakhstan and Fund staff estimates.

$1 /$ New classification scheme introduced in early 2003. It is thus difficult to compare over time the level of classified assets, but both the FSA and banks are of the opinion that the new policy is stricter.

2/ Nonperforming loans excluding loans classified as doubtful but on time increased from 12.2 percent of total loans in March 2003 to 13.1 percent in December 2003.

3 / Excluding deposits and loans indexed to foreign exchange.

4/ At end-2003, the trading portfolio amounted to 11.8 percent of assets. 
Figure 1. Capital Adequacy Ratio Adjusted for an Increase in Classified Loans, preliminary data of January 1, 2004

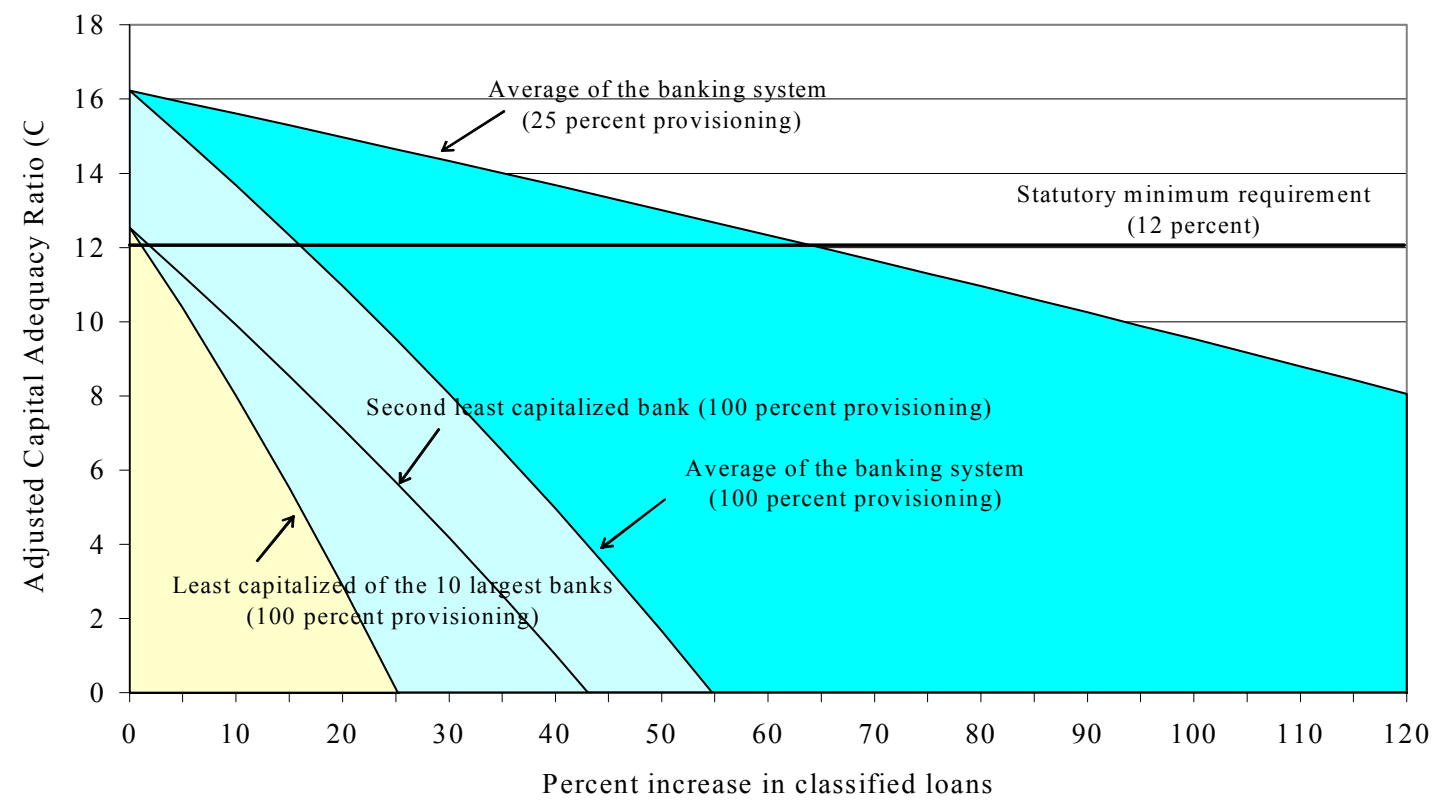

statutory requirement. While it would take a large 55 percent increase to lead to its insolvency (Figure 1), and for the least capitalized of the 10 largest banks, it would take only a 25 percent increase in classified loans requiring full provisioning. ${ }^{10}$ Rapid credit growth often coincides with lax credit risk assessments, which the authorities in 2003 counteracted with stricter loan classification and provisioning rules. Continued diligence is warranted, which can best be achieved by ensuring adequate resources to conduct the scheduled number of comprehensive on-site inspections.

\section{Some banks are vulnerable to credit risks from specific economic sectors.}

Although there are restrictions on large exposures and substantial improvements have been made since the 2000 FSAP, loan concentration to large business groups remains an issue. Although the definition of group exposure is suitably broad, there is not much discretion for the supervisory authority to deem parties to be part of a single group when that is the

\footnotetext{
${ }^{10}$ Another exercise would be to assume 100 percent provisioning of current classified loansexcluding loans classified as doubtful but on time-less current provisions. Applying this methodology on preliminary data from January 1, 2004, the CAR would decline by about $51 / 2$ percentage points for the banking system. Five of the 10 largest banks, would, in this scenario, breach the statutory CAR but remain solvent. The estimates are based on preliminary end-2003 data.
} 
substance of the relationship. ${ }^{11}$ Several of the 10 largest banks would be severely affected if significant provisioning were to be required for loans to agriculture, oil, and construction. The oil sector funds itself mainly from sources outside Kazakhstan, capturing less than 7 percent of total bank lending. For illustrative purposes, assuming an extreme case where all loans to the oil sector became nonperforming and full provisioning was required, the adjusted CAR for the banking system would fall to the statutory requirement, and 4 of the 10 largest banks would breach the statutory requirement. Severe problems in the construction sector would also adversely affect some of the large banks. It is encouraging that the authorities are considering improving monitoring of real estate prices, particularly in large population centers.

\section{Prudential indicators for liquidity risk suggest that the banking system is liquid} on aggregate, but liquidity ratios do not fully reveal the extent of some banks' reliance on potentially volatile wholesale funding. The loan-to-deposit ratios for the 10 largest banks range from 56 percent to 120 percent. A few of the larger banks use special purpose vehicles - reportedly for tax purposes - to solicit funding abroad, illustrating the importance of analyzing liquidity on a consolidated basis. It is important to monitor whether the issued bonds have special covenants (embedded options). As previously mentioned, the Deposit Insurance Fund has introduced interest rate ceilings on deposits to prevent weak banks from offering excessive interest rates, which suggests that some banks may have liquidity constraints that should be investigated.

\section{Although the aggregate limit on exchange rate risk is quite high according to} international practice, the limit on individual currencies depends on the rating of the country, which reduces the risk. However, the pertinent regulation does not include assets and liabilities denominated in tenge but indexed to foreign exchange in the calculation of the net open position in foreign exchange. The popularity of such instruments has reportedly faded since the 1998 Russian crisis. Nevertheless, indexed instruments, depending on the type of indexation, should be included for completeness, and information about their use should be compiled. Derivatives are included in the calculation of the net open position in foreign exchange, but the regulation does not specify how to treat currency options. Banks, however, are also exposed to indirect foreign currency risk, which may be substantial, but the size of the problem is difficult to gauge due to lack of data. Although appreciation expectations currently reduce this risk, consideration should be given to conducting occasional surveys to better estimate the indirect exchange rate risk.

${ }^{11}$ Exposure to a single borrower connected to the bank with special relations is limited to 10 percent of equity capital and the aggregate of such exposures shall not exceed 100 percent, while for other borrowers the limit is 25 percent (with not more than 10 percent uncollateralized), but the aggregate of large exposures is not limited. Consideration should be given to gauge the impact of large business groups on the banking system. The impact on the CAR of the various banks could be estimated, if the business group with the largest exposure to the banking system failed. The information to make such simulations is available in the FSA's large loan database. 


\section{B. Nonbank Financial Institutions}

32. Rapid passage of several laws for the insurance industry, pension funds, and securities markets has created a gap between the regulatory framework and the implementation capacity of both the industries and their regulators. Implementation of existing laws should be the near-term focus. Several additional laws - including one on investment funds and one on securitization - are currently being drafted. While the securitization law could provide a framework for asset-backed securities, careful consideration should be given to the types of assets that could be securitized and to the appropriate reporting of risks. The insurance industry reports that the government is considering making additional insurance products compulsory. Although some market participants expressed interest in seeing these laws passed, the industry's ability to absorb further legislation at this time is doubtful.

\section{Steady contributions to pension funds and the absence of a vibrant capital} market to absorb such funds necessitate a combination of supervisory diligence and capital market development. The dominance of banks and banking products in the financial sector and substantial relationship between the financial and real sectors may hamper capital market development. The low level of competition in some key economic sectors and the existence of influential financial-industrial groupings limit the number of potential issuers in the market. The mixed legacy of the first wave of privatizations, some enterprises' concerns over consequences from increased transparency, and the cost of listing may discourage issuance of corporate securities.

34. The investment strategies of pension funds are currently focused on high returns through high-yield, short-term investments. This is in part due to lack of long-term financial assets to match their liabilities and in part due to a focus on short-term return with a view to gain market share rather than on minimizing risks. ${ }^{12}$ Neither regulators nor industry participants appear to fully appreciate the risks attached to this practice. This short-term highyield focus exposes social safety net assets to higher reinvestment and issuer risk. Lamenting the decline in the yield on government securities - a substantial portion of portfolios by statute - fund managers select assets that are highly vulnerable to exchange rate risk-both foreign and currency indexed assets. Foreign investments, including index funds, would offer diversification possibilities and reduce the risk of investing in securities issued by domestic corporations with poor governance and offering low rates of return. However, low interest rates and the recent appreciation of the currency have resulted in negative returns on some foreign investments.

35. There is no easy solution for generating long-term financial assets for pension funds, but efforts to encourage such issuances must be continued. Instruments to satisfy pension funds' needs for investment securities are seen as a driving force for market

\footnotetext{
12 The authorities may want to reassess whether the current returns and contribution rates are sufficient to cover the pension projections.
} 
development. To date, only mortgage-backed securities have been issued to help meet this demand. For equities, market participants appear to expect a magic bullet in the form of a government-backed blue chip - perhaps through a privatization - that would invigorate the market. Other issuers are unlikely to enter the stock market in the near future.

36. An active, predictable public debt market is lacking. The government does not presently need to increase its borrowing due to revenue from the oil sector and a cautious fiscal stance. However, domestic government issuances can be structured to enhance development of the tenge-denominated debt market by establishing benchmarks and a yield curve.

37. Regardless of the nature of issuers and securities, information disclosure is at the heart of any viable financial market. Ownership, governance, accurate descriptions of products and inherent risks form the foundation for financial transactions, and thus market development. A corporate governance ROSC assessment to evaluate the implementation of the existing voluntary governance guidelines would help identify measures to further the confidence in the market for corporate securities. At the same time, an education campaign to explain to the public the potential advantages and uses of nonbank financial products would be useful. While industry associations are well placed to take the lead in organizing such campaigns, the government should support such drives and ensure that information about the risks is transparent to consumers.

38. The development of a viable insurance industry is hampered by the lack of the industry's ability to measure risks and, hence, to set adequate reserves and realistic prices for its products. The prospect of more compulsory insurance products, particularly in areas that are traditionally hard to insure and reinsure, such as crop insurance, could exacerbate the risks arising from insufficient database and actuarial capacity. Until substantial statistical information has been collected systematically, the most successful insurance products are likely to be third-party liability and property insurance.

\section{AsSessments AND UPDATES OF SELECTED STANDARDS AND Codes ${ }^{13}$}

\section{A. Reassessment: Basel Core Principles for Effective Banking Supervision}

39. The re-assessment shows substantial improvement since the 2000 assessment, although several shortcomings remain. Compared to the 2000 assessment, more principles were compliant or largely compliant and no principles were non-compliant. Several important measures have recently been taken, including on consolidated supervision and riskmanagement. These are excellent initiatives, but it was not possible for the assessors to verify

${ }^{13}$ An update means that progress and setbacks were documented, but the principles were not re-rated. The updates of the IOSCO Principles on Securities Regulation and IAIS Insurance Principle were more comprehensive. 
their implementation due to their recent introduction. The FSA, which became operational January 1, 2004, still has to establish a track record. A ROSC summarizing the main findings can be found in Appendix II.

\section{B. Update: IOSCO Principles on Securities Regulation}

40. Since the 2000 FSAP, Kazakhstan has made marked improvements in the legal framework for securities regulation. The new laws and regulations are ambitious, and broadly consistent with international practices, but their effective implementation is needed to help the industry develop further.

41. The FSA capital market and pension supervision department faces competing priority challenges. Staff of about 30 for the securities market and pension funds (10 each in the on-site and off-site divisions), are designated to the supervision of 120 capital market participants, each of whom reports at various frequencies. A disproportionate share of resources will increasingly be required in monitoring pension funds, owing to their rapid accumulation of funds as well as their social importance. This could lead to undetected vulnerabilities in the rest of the securities market, as it develops.

42. The supervision of both securities and pensions should be reassessed. Less frequent reporting may suffice on the part of some participants. This would also free capacity for more analysis of the collected reports. In line with the practice of developed countries, continuous dialogue between the regulator and the industry would increase supervisory effectiveness.

\section{Update: IAIS Insurance Principles}

43. The 2000 FSAP recommended adoption of new insurance legislation that would be consistent with international practice, prescription of accounting principles and standards on auditing and financial reporting, development of an actuarial profession, and upgrading supervision. New legislative requirements, passed in December 2003, are just beginning to be implemented. Since January 1, 2003, it has been compulsory for financial institutions, including insurance companies, to use international financial reporting standards (IFRS), but small insurance companies may in practice find it difficult to apply them. Several challenges remain, including upgrading supervision to meet the requirements of the new legislation, strengthening implementation and enforcement practices, developing an actuarial profession and a reliable statistical foundation and database.

\section{Update: Core Principles for Systemically Important Payment Systems}

\section{The 2000 FSAP assessment found many principles observed or broadly} observed, but also identified important weaknesses. Both the system for large-value and time-sensitive interbank payments, which since has become the Interbank System of Money Transfers (ISMT) - a real-time gross settlement system — and the System of Retail Payments (SRP) - a multilateral netting system for small electronic retail payments - were considered systemically important. Weaknesses were mainly related to the SRP. 
45. Since the 2000 FSAP, the NBK, in collaboration with the Kazakhstan Interbank Settlement Center, has continued reforming the payment systems. In 2003, a new assessment of the ISMT was done. All principles were rated observed or broadly observed. The assessor suggested clarifications to ensure consistency between the Law on Payments and Money Transfers and the Bankruptcy Law regarding real-time finality, but the authorities find the legal arrangements defining irrevocability adequate.

46. Since the $\mathbf{2 0 0 0}$ assessment, concerns regarding security of the payment system have emerged but have been promptly addressed. On-site inspections of participants in the payment system have been undertaken by the NBK as a measure to further strengthen the overall security and integrity of the payment systems. Members of the payment systems that do not follow appropriate security procedures should be sanctioned.

\section{E. Update: Practices on Transparency in Monetary and Financial Policies}

47. The 2000 assessment concluded that the NBK was relatively transparent in its conduct of monetary policies, but it also emphasized areas that required improvements. Specifically, the assessor concluded that the central bank law should list general criteria for the removal of the heads and members of the governing body of the central bank. In addition, the 2000 assessment found that the information on the structure and functions of the central bank's policymaking body was not available to the public. It also was found that disclosed financial statements lacked information on auditing policies and that some documents on internal auditing and practices of the internal audit division were not publicly disclosed.

48. The NBK has further strengthened its transparency of monetary policies, but some shortcomings still remain. In 2002, the NBK announced plans to move to an inflation targeting framework. In March 2003, the NBK successfully completed subscription to the Special Data Dissemination Standards (SDDS) and has since started publishing data on the template on international reserves and foreign currency liquidity. Information on the terms of refinance and other central bank facilities are now published. The schedule on the meetings of the main policymaking body is published along with its working-plan. The NBK now provides information on internal audit in its annual report. The NBK publishes regulations describing rules and procedures for its relationships and transactions with counterparties. In spite of several amendments to the central bank law, it does not yet spell out the criteria for removal for the members of the governing bodies of the NBK. Although Article 26 of the law on Public Service does stipulate that misdeeds are grounds for dismissal, it does not protect the members from arbitrary dismissal.

49. The authorities maintain that the guiding principles pursued by the FSA will remain unchanged from those practiced by the NBK, but the new legal framework does not cover all issues previously addressed by the central bank law. For example, the FSA law does not set up modalities of accountability. The FSA is not required to publish audited financial statements of its operating expenses and revenues. So far, there is no internal audit function established and internal procedures have yet to be established. The FSA also has to establish its own public information service and publication program. Public information on 
financial sector issues is currently published on the NBK website and in its publications. The FSA law outlines the areas of interaction with the NBK, and a detailed agreement has been signed by the two institutions.

\section{F. Assessment: Prevention of Money Laundering and Combating Financing of Terrorism}

50. Kazakhstan has taken initiatives to prevent money laundering and financing of terrorism, but the legislative framework does not yet observe international standards. The task of drafting a law on anti-money laundering and combating the financing of terrorism (AML/CFT) has been given to the Agency Fighting Economic and Corruption Crimes. ${ }^{14}$ The Criminal Code recognizes money laundering as a financial crime, but its legal definition does not yet meet recognized international conventions and standards. The banking secrecy provisions subject anyone disclosing suspicious transactions, even to authorized bodies, to criminal sanctions. A financial intelligence unit (FIU) does not yet exist. Although the financing of terrorism has been added to the definition of terrorist activity, which will allow authorities to pursue the financing of terrorism in some circumstances, financing of terrorism is not criminalized per se and therefore this provision does not fully satisfy the requirements on combating the financing of terrorism or on offering international cooperation in financing of terrorism cases. A summary of the assessment- the ROSC of the AML/CFT standards - can be found in Appendix III.

${ }^{14}$ It is anticipated that the law will be adopted by the parliament sometime before end- 2004 . 


\section{Kazakhstan: Progress SINCE The 2000 FSAP Mission}

\begin{abstract}
Main Recommendations of the 2000 FSAP Mission Basel Core Principles for Effective Banking Supervision Strengthen authority to obtain information from subsidiaries, parents and affiliates of banks with a view to facilitate monitoring of direct and indirect ownership, supervision of connected borrowers as well as collect, review and analyze prudential information on both a solo and a consolidated basis.

Amend the legal framework to ensure that in the unlikely event the court subsequently finds that the NBK has acted without due cause, the compensation is limited to monetary damages. The ability of bank shareholders to obtain court orders overturning decisions of the NBK, including revocation of licenses, is a serious deficiency.

Avoid the NBK Board's practice of granting exemptions without requiring a documented time-bound plan on reaching compliance. Although prudential standards are in place, they are not always enforced.

Address differences from International Accounting Standards, particularly regarding loan loss provisions. The shortage of qualified accountants should be addressed.

Introduce capital requirements for market risks.

Explicit money laundering provisions should be introduced.
\end{abstract}

Create an environment conducive for the development of a cadre of skilled supervisory professionals.

\section{IOSCO Principles on Securities Regulation}

Strengthen legislation, including enforcement powers.

Fully disclose timely and accurate financial results and other information relevant for investors.

Ensure that accounting and auditing standards are of high and of internationally accepted quality.

Make market intermediaries comply with a code of conduct that aims to protect the interest of their clients.

\section{Progress Achieved since 2000 FSAP}

Amendments to the banking law provide authority to obtain information from bank affiliates and to obtain full details on related parties of almost all banks. In 2003, consolidated prudential norms were introduced and are being implemented.

While the recommended legal amendment has not been introduced, education of the judiciary has resulted in decisions of the supervisory authority which are now less likely to be upheld when subject to challenge in court.

Exemptions from prudential requirements have reportedly not been provided since 2000 .

According to the FSA, all banks currently report compliance with all prudential standards. Effective January 1, 2003, banks have been required to use IFRS. Implementation is still a challenge, and the shortage of qualified accountants will have to be addressed over time. Not yet addressed.

"Know your customer" requirements were introduced in June 2000. An AML law and the creation of a Financial Intelligence Unit (FIU) are still required.

Salary levels are now reportedly closer to commercial bank rates, but every bank supervision division has staff vacancies.

New legislation enacted in 2003 provides a clear and consistent regulatory framework, strengthens enforcement powers, but it is too soon to assess its implementation.

Previous loopholes for closed joint stock companies have been eliminated. The FSA can now sanction wrongdoing. An electronic filing and disclosure system for registered offerings and periodically reported information is under consideration.

International Financial Reporting Standards (IFRS, formerly IAS) are compulsory for financial institutions, while nonfinancial entities will use them beginning January 2005. International Standards on Auditing (ISA) are now applied by financial institutions. In practice, however, only the larger financial institutions are able to apply IFRS.

In 2002, a code of conduct (Ethics Code) for market intermediaries and qualified specialists 
Have in place procedures to deal with failure of a market intermediary.

Introduce regulation to detect and deter market manipulation.

\section{IAIS Insurance Supervisory Principles}

Adopt new insurance legislation to better observe best international practices.

Upgrade supervision.

Monitor closely changes in control of insurance companies and support rules by stronger legislation.

Boards were not required to have investment policies that would restrict the maximum exposure to any single counterparty, rules regarding the safekeeping of assets, or requirements that would deal with the appropriate matching of assets and liabilities. Strengthen provisions on governance, including requirements for internal controls.

Ensure that the accounting and auditing profession in the country becomes familiar with insurance business and its special accounting characteristics.

Develop an actuarial profession.

\section{CPSS Core Principles for Systemically Important Payment Systems}

Clarify some legal issues.

Ensure that the multilateral netting system has timely settlement at the end of each day in the event of the inability to settle by the participant with the largest single settlement obligation. was established. It includes recommendations. The code of conduct established by the Kazakhstan Stock Exchange is mandatory for broker-dealers, who are members of the Exchange.

Legislation empowers the FSA to inspect and monitor liquidation and reorganization procedures of licensees. The FSA has formed the Financial Organizations Liquidation Department to control the liquidation process. An insurance scheme to protect assets of investors dealing with a failed market intermediary does not yet exist.

A market surveillance system is currently being developed. In practice, the illiquidity of the market and lack of order interaction currently make effective market surveillance difficult.

New insurance legislation was adopted in 2000, whereupon regulations have been revised to better observe international practices.

Regulations have been upgraded. Insurance companies are now required to submit rules concerning conditions for each type of insurance they conduct for approval by the FSA.

Legislation has been improved, but rules on "changes in control" are still incomplete. A special regulation that deals with the appropriate matching of assets and liabilities for the investment policy of insurance companies has been adopted.

Standards for the role and responsibilities of the board of directors of insurance companies, a system for internal control of the management, and internal audit have been introduced.

Two new regulations address the financial reporting of insurance companies, reinsurance, and insurance brokers.

The Society of Kazakhstani Actuaries, which was established in 2001/02, currently has 50 members, 30 of whom have an actuary license.

A reassessment in 2003 found that the legislative framework had been clarified, but additional clarification would be useful. The authorities do not recognize a potential conflict between the payment system law defining finality and the bankruptcy law.

The payment systems have since been further reformed. The retail payment system is therefore no longer considered systemically important. Furthermore, procedures are in place to reduce the risk for an unwind in the retail payment system. 
Code of Good Practices on Transparency in Monetary and Financial Policies Ensure legislation provides that high level officials can only be removed for cause, and that in the event of such a removal, the No change. The new legislative framework for reasons be made public.

Disclose fully internal governance procedures ensuring the the FSA has the same deficiencies. integrity of the NBK operations.

More information is being published in the NBK Annual Report. The FSA has just been established. 


\section{REPORT ON THE OBSERVANCE OF STANDARDS AND CODES-SUMMARY ASSESSMENT OF BANKING SUPERVISION}

1. The assessment of implementation of the Basel Core Principles for Effective Banking Supervision has been completed as part of a Financial Sector Assessment Program update. It requires a review of the legal framework, both generally and as specifically related to the financial sector, and a detailed examination of the policies and practices of the institutions responsible for banking supervision. The assessment team received good cooperation from its counterparts and received generally all information required. ${ }^{15}$

\section{Institutional setting}

2. The newly created Agency of the Republic of Kazakhstan on Regulation and Supervision of Financial Markets and Financial Institutions (FSA) is the body responsible for banking supervision. The National Bank of Kazakhstan (NBK) also retains responsibility for broad financial sector stability. Significant changes have been implemented in the legal foundation for supervision and its practical implementation since the original FSAP, both in response to issues identified in the 2000 assessment of implementation of the Core Principles, and in response to evolving international best practices.

\section{General preconditions for effective banking supervision}

3. The banking sector in Kazakhstan has benefited from a period of very strong economic growth, which has increased the demand for credit. The growth of household deposits has lagged the growth of the banking sector overall, with the result that much of the banking sector is dependent on wholesale funding. There is a wide variation among the banks in their depth of management and level of risk management, and smaller banks in particular may face serious challenges in maintaining their viability.

4. The quality of government infrastructure has been improving rapidly. There has been a significant improvement of commercial law, including provisions for the registration of collateral and enforcement of security interests. The judiciary is said be developing greater familiarity with commercial and banking matters, making decisions more predicable, and in the view of some market participants, more likely to be based on appropriate interpretations of the law.

5. The distortionary effects of some aspects of the tax system are of concern. A broader review of fiscal policies would be appropriate. Of particular concern from a prudential perspective is the restriction on the amount of interest paid that can be deducted from income for tax purposes, which has the adverse effect of driving up loan interest rates so that banks can continue to earn an equivalent after-tax return for shareholders. Higher loan rates can in

${ }^{15}$ Michael Andrews (World Bank consultant) and Tonny Lybek (MFD, IMF). 
turn have a detrimental effect on asset quality. Kazakhstani banks have been required to use International Financial Reporting Standards (IFRS - previously International Accounting Standards-IAS) since January 1, 2003. While all banks are meeting the letter of the law, some of the smaller banks, in particular, may not have made the investment to fully convert their internal systems to IFRS.

6. The deposit insurance regime was significantly revised in 2003, with participation made mandatory for all banks licensed to accept deposits effective January 1, 2004. There is no practical experience with the deposit insurance fund, as only one of the four banks that failed since its inception in 1999 was a member of the fund, and in this case, the NBK made extraordinary ex gratia payments to compensate most depositors. The introduction by the deposit insurance fund in 2003 of interest rate ceilings on deposits is a cause for concern. Payment of excessive deposit rates by some banks is likely an indicator of increasing risk of loss on the part of the deposit insurance fund, but timely supervisory action is the more appropriate response.

\section{Main findings}

7. The implementation of the Basel Core Principles for Effective Banking Supervision (BCP) has improved substantially in Kazakhstan since the original assessment was completed in the first quarter of 2000. Not only have significant amendments been made to the legal foundation of supervision, but there have also been improvements in practical application. Significant legal improvements regarding consolidated supervision and risk management were introduced in late 2003. Effective implementation of these measures would improve the assessment of six principles currently graded as materially non-compliant.

\section{Objectives, Autonomy, Powers, and Resources (CP 1)}

8. Kazakhstan's level of compliance with core principle one has increased due to changes in the legal framework for enforcement action, and more importantly, evolution in the judicial system, which is now inclined to uphold supervisory actions if subject to challenge in the courts. The creation of a single supervisory agency has addressed earlier concerns about information sharing among supervisory authorities. A detailed agreement on cooperation has just been signed by the FSA and the NBK, which addresses the provision of premises and services for the new agency, and it outlines specific information sharing measures. One concern is the fact that the new agency lacks some of the elements that are intended to ensure the operational independence of the NBK. It would be better for the Chairman and Deputy Chairman of the new agency to serve fixed terms, with the provision that they can only be removed for reasons specified in law, and that the reason for their dismissal be made public if they do not serve a full term. Article 922 of the Civil Code provides that the state treasury will pay the costs of any court judgment arising from action or non-action by an official in connection with public administration. 


\section{Licensing and Structure (CPs 2-5)}

9. Kazakhstan has achieved a high level of compliance with these principles. The introduction of a legal requirement for affiliates of banks to provide information needed for supervisory purposes has been effectively used to determine the beneficial owners of almost all significant ownership stakes in Kazakhstani banks. New procedures, including monthly reports from share registries, have almost eliminated the earlier problem of changes in significant ownership without the knowledge and approval of the supervisory authority.

\section{Prudential Regulations and Requirements (CPs 6-15)}

10. Compliance with these principles has improved since 2000. Steps have already been initiated to address the remaining major weaknesses. Effective implementation of recently introduced supervisory requirements for risk management and group wide prudential limits would significantly improve the assessment of five of these principles. Introduction of the planned law on anti-money laundering, establishment of a financial intelligence unit, and amendment of pertinent bank secrecy provisions will provide the needed legal foundation to improve compliance with current standards for the prevention of the use of banks by criminal elements.

\section{Methods of Ongoing Supervision (CPs 16-21)}

11. The standard of onsite and offsite supervision is generally good, with significant improvements having been made since 2000 in the depth of offsite analysis, and in the supervisors' understanding to group structure and banking activities. The legal amendment to permit the supervisory authority to obtain information from bank affiliates has been put to good use. The most important remaining issue in this group of principles is consolidated supervision. The assessment could be substantially improved through the effective implementation of the group wide prudential limits introduced in late 2003, and development of the agency's current plans to ensure appropriate internal coordination of the supervision of financial groups.

\section{Formal Powers of Supervisors (CP 22)}

12. Exercise of remedial powers appears much improved. Exemptions from prudential requirements are no longer granted by the supervisory authority. Banks with identified weaknesses are subject to more intensive monitoring, and, according to the FSA, all banks are currently reporting compliance will all prudential norms. Nevertheless, the introduction of deposit interest rate ceilings by the deposit insurance fund in 2003 is cause for concern. Resorting to administrative measures to stop banks from paying interest rates far above prevailing market rates is likely to be indicative of banks suffering from mismanagement, illiquidity and/or insolvency. This suggests that may be instances of problem banks not, in fact, being promptly identified and addressed. 


\section{Cross-Border Banking (CPs 23-25)}

13. The importance of implementing these principles has increased significantly since 2000, as Kazakhstani banks are now much more active internationally. Several banks have established foreign operations and further expansion abroad is in the planning stage. Reaching full compliance will require the development of supervisory approaches focusing on the oversight of foreign operations by bank management, in addition to development of agreements and memoranda of understanding with foreign supervisors that result in effective exchange of information and coordination of activities.

Table 1. Recommended Action Plan to Improve Compliance with the Basel Core Principles

\begin{tabular}{|c|c|}
\hline Reference Principle & Recommended Action \\
\hline 1.1 Objectives & $\begin{array}{l}\text { - The recently signed detailed agreement between FSA and } \\
\text { NBK should be implemented. }\end{array}$ \\
\hline 1.2 Independence and resources & $\begin{array}{l}\text { - It should be stipulated in law that high level officials at the } \\
\text { FSA can be removed only for cause with the reasons made } \\
\text { public. } \\
\text { - Fill existing staff vacancies. }\end{array}$ \\
\hline 1.4 Enforcement powers & $\begin{array}{l}\text { - Legal amendment to explicitly permit the supervisory } \\
\text { agency to exercise judgment should be adopted. }\end{array}$ \\
\hline 1.6 Information sharing & $\begin{array}{l}\text { - The recently signed detailed agreement between FSA and } \\
\text { NBK should be implemented. }\end{array}$ \\
\hline 3. Licensing & $\begin{array}{l}\text { Due consideration should be given to whether the proposed } \\
\text { legal and managerial structure would hinder effective } \\
\text { supervision. }\end{array}$ \\
\hline 5. Investment criteria & $\begin{array}{l}\text { - Establishment or acquisition of a subsidiary if it might } \\
\text { impair effective supervision should be prohibited. }\end{array}$ \\
\hline 6. Capital adequacy & $\begin{array}{l}\text { Effective implementation of the recently introduced group } \\
\text { wide prudential requirements, including regularly } \\
\text { calculating the capital adequacy ratio on a consolidated } \\
\text { basis. }\end{array}$ \\
\hline 7. Credit policies & $\begin{array}{l}\text { - Effective implementation of the prudential requirements on } \\
\text { credit risk management introduced in December } 2003 \text {. }\end{array}$ \\
\hline 8. Loan evaluation and provisioning & - Fine-tune the new loan loss provisioning requirements. \\
\hline 9. Large exposure limits & $\begin{array}{l}\text { Effective implementation of the recently introduced group } \\
\text { wide prudential requirements. }\end{array}$ \\
\hline 10. Connected lending & $\begin{array}{l}\text { - Obtain greater certainty over time that all related parties } \\
\text { transactions are actually identified and reported. }\end{array}$ \\
\hline 11. Country risk management & $\begin{array}{l}\text { - Effective implementation of the prudential requirements on } \\
\text { risk management introduced in December } 2003 \text {. }\end{array}$ \\
\hline 12. Market risks & $\begin{array}{l}\text { - Effective implementation of the prudential requirements on } \\
\text { risk management introduced in December } 2003 \text {. } \\
\text { - Introduce capital requirements for market risk. }\end{array}$ \\
\hline 13. Other risks & $\begin{array}{l}\text { - Effective implementation of the prudential requirements on } \\
\text { risk management introduced in December } 2003 \text {. }\end{array}$ \\
\hline 14. Internal audit and control & $\begin{array}{l}\text { - Continued improvement in the application by banks of the } \\
\text { prudential requirements for internal control and audit. }\end{array}$ \\
\hline
\end{tabular}




\begin{tabular}{|l|l|}
\hline \multicolumn{1}{|c|}{ Reference Principle } & \multicolumn{1}{|c|}{ Recommended Action } \\
\hline 15. Money laundering & $\begin{array}{l}\text { Introduce planned anti-money laundering law, a Financial } \\
\text { Intelligence Unit (FIU), and amend the pertinent bank } \\
\text { secrecy provisions. } \\
\text { Develop specific prudential guidelines for banks in } \\
\text { conjunction with broader work on AML/CFT issues. }\end{array}$ \\
\hline 16. Onsite and offsite supervision & $\begin{array}{l}\text { Development of effective internal policies within the FSA to } \\
\text { coordinate the work of the division responsible for financial } \\
\text { conglomerates with the functional supervisors. }\end{array}$ \\
\hline 18. Offsite supervision & $\begin{array}{l}\text { Further improve the depth of analysis, particularly regarding } \\
\text { liquidity and refinancing risks. }\end{array}$ \\
\hline $\begin{array}{l}\text { Review the volume and frequency of data collection with a } \\
\text { view to eliminating daily and weekly analysis, except of } \\
\text { identified problem banks. }\end{array}$ \\
\hline 20. Consolidated supervision & $\begin{array}{l}\text { Effective implementation of the recently introduced group } \\
\text { wide prudential requirements. } \\
\text { Development of effective internal policies within the FSA to } \\
\text { coordinate the work of the division responsible for financial } \\
\text { conglomerates with the functional supervisors. }\end{array}$ \\
\hline 21. Accounting standards & $\begin{array}{l}\text { Ensure open channels of communication with auditors. } \\
\text { Ensure prompt action to address identified problem banks. }\end{array}$ \\
\hline 23. Remedial measures & $\begin{array}{l}\text { Develop a supervision module to focus specifically on the } \\
\text { oversight by bank management of foreign establishments. }\end{array}$ \\
\hline 24. Host country supervision & $\begin{array}{l}\text { Develop working relationships with foreign supervisors, } \\
\text { including information exchange and coordination of } \\
\text { activities. }\end{array}$ \\
\hline 25. Supervision over foreign banks' establishments & $\begin{array}{l}\text { Develop stronger working relationships with home country } \\
\text { supervisors. } \\
\text { Assess home country supervisors' capacity for consolidated } \\
\text { supervision. }\end{array}$ \\
\hline
\end{tabular}

\section{Authorities' response}

14. The authorities were broadly in agreement with the assessment and found it unbiased and useful. The authorities have recently issued regulations on consolidated supervision and risk management, but agreed that insufficient time had passed to assess the implementation and effectiveness of these regulations. 


\section{REPORT ON THE OBSERVANCE OF STANDARDS AND CODES-SUMMARY ASSESSMENT OF AML/CFT}

1. This Report on the Observance of Standards and Codes (ROSC) for the FATF 40 Recommendations for Anti-Money Laundering and 8 Special Recommendations Combating the Financing of Terrorism was prepared by a team composed of staff of the International Monetary Fund (IMF), World Bank (WB), and a criminal law expert not under the supervision of the IMF and the $\mathrm{WB}$, selected from a roster of experts to assess criminal law enforcement and non-prudentially regulated financial activities. ${ }^{16}$

2. This report provides a summary of the level of observance with the FATF $40+8$ Recommendations, and provides recommendations to strengthen observance. The views expressed in this document are those of the assessment team and do not necessarily reflect the views of the government of Kazakhstan or the Boards of the IMF or the World Bank.

\section{Information and methodology used for the assessment}

3. In preparing the detailed assessment, IMF and WB staff reviewed the relevant antimoney laundering (AML) and combating the financing of terrorism (CFT) laws and regulations, including the supervisory and regulatory systems in place to deter money laundering and financing of terrorism among prudentially regulated financial institutions. The assessment is based on the information available at the time it was completed (February 24, 2004).

\section{Main findings}

4. Kazakhstan's rapid economic growth has been largely based on substantial oil, gas, and mineral reserves, and privatization process. Its geographic location, however, renders it a convenient drug trafficking corridor. These factors, together with organized crime, regional insecurity, issues regarding transparency in the management of natural resources (particularly in the energy sector), and the need to encourage foreign investment, create substantial challenges with respect to limiting risks related to money laundering and terrorist financing. Since the links between drug trafficking and terrorism in the region could present serious challenges to regional and economic development, delay in implementation of appropriate AML/CFT policies and procedures could impede Kazakhstan's development efforts.

\footnotetext{
${ }^{16}$ The assessment team comprised Ms. Joy K. Smallwood (Legal Department, IMF), Ms. Cari Votava (Senior Financial Specialist, World Bank), and Mr. Evgeniy Volovik (Independent AML/CFT Law Enforcement Expert, KFM, Russia). The roster of law enforcement experts is based on the names of competent persons identified by the FATF, FSRBs, the United Nations, and the Egmont Group. The law enforcement expert, who was not under the supervision of IMF and WB staff, reviewed the capacity and implementation of criminal law enforcement systems. The law enforcement expert's assessment and comments are in italics.
} 
5. While Kazakhstan has criminalized money laundering, its definition does not yet meet international standards. No financial intelligence unit (FIU) yet exists, and bank secrecy provisions impose criminal liability upon those who disclose suspicious transaction data even to authorities authorized to act on such information. At the same time, government officials from various enforcement and financial sector regulatory agencies have participated in AML/CFT training programs over the past year, which indicates emerging political will to build a legal framework to combat money laundering (ML) and financing of terrorism (FT).

\section{Criminal justice measures and international cooperation}

\section{Criminalization of ML and FT}

6. Although Kazakhstan has not yet enacted a law on anti-money laundering or combating terrorist financing, coordination of the drafting of such a law has begun and been given to the Agency Fighting Economic and Corruption Crimes. The Criminal Code recognizes money laundering as a financial crime, but its legal definition does not yet meet recognized international standards.

7. While financing of terrorism has not been criminalized as a separate offense from terrorism in the Criminal Code, financing of terrorism is included within the definition of "terrorist activity" in the Law of the Republic of Kazakhstan of July 13, 1999 No. 416-1 on Combating Terrorism (Law No. 295, as amended, Feb. 19, 2002). Although this will allow the authorities to pursue the financing of terrorism in some circumstances, it does not fully satisfy the requirements on combating financing of terrorism and international cooperation as set out in the International Convention on the Suppression of the Financing of Terrorism.

8. These factors, together with the fact that Kazakhstan remains a relatively cash-based economy, impede the ability of enforcement authorities to pursue investigations and convict criminals for organized crime, money laundering, and terrorist financing. Officials also recognize that there exists a significant unregulated economy, which thrives outside the formal financial sector. As sectors such as gas, oil, and metals are generally known as presenting higher risks for money laundering, appropriate controls of these sectors should be considered.

9. The UN Security Council Resolutions relating to the prevention or suppression of financing of terrorism have not been fully implemented in Kazakhstan, although the authorities have begun to circulate the UN terrorist lists to financial institutions. However, the screening of clients against such lists is not a legal obligation, nor can noncompliance be sanctioned. The authorities cannot freeze, without delay, funds or other property of terrorists or terrorist organizations designated by the UN or by individual governments without first initiating a court action in Kazakhstan. While this may be done expeditiously, no action regarding freezing of assets can be taken until a judge in Kazakhstan has ruled that the individual or the legal entity is a terrorist or a terrorist organization. 


\section{Confiscation of proceeds of crime or property used to finance terrorism}

10. The confiscation regime in Kazakhstan has both property and value-based provisions, but is not mandatory. It applies to economic benefits deriving from any criminal offense. Confiscation requires a criminal conviction, and the freezing and seizing of assets are available on a provisional basis. Assets and proceeds from conduct other than the offense in question are subject to provisional measures and may be subject to confiscation at the sole discretion of the judge. Defendants, who have fled may be prosecuted when absent, and confiscation of a fugitive's assets is also permissible.

11. Seizing, freezing, and confiscation appear to be used only as an additional penalty for criminal offenses, but could also help discourage money laundering, terrorist financing, and other organized criminal activities. The lack of provisions to permit expeditious seizing or freezing bank accounts or other accounts without delay is a serious impediment to preventing crimes and accumulating evidence to build cases against money launderers and those involved in organized crime. In addition, legal mechanisms should be available to allow the freezing or seizure of property, proceeds, and/or assets used or intended for use in the financing of terrorism.

\section{The FIU and processes for receiving, analyzing, and disseminating intelligence at the domestic and international levels}

12. Although, there is no FIU in Kazakhstan, the authorities are in the process of drafting and AML/CFT law, which would provide the legal authority for its establishment. Creation of a FIU should be a priority, so details of transactions, which are suspected to result from criminal activity, can be forwarded to a body that can analyze the data and forward information about transactions that warrant further investigation and prosecution to pertinent law enforcement authorities.

\section{Law enforcement and prosecution authorities, powers and duties}

13. Methods to combat money laundering and financing of terrorism need to be further developed. Training of law enforcement officials is crucial to acquire skills and learn the latest developments and techniques in areas of asset tracing, money laundering, and the financing of terrorism, as this is a rapidly developing field of police work. Law enforcement agencies in Kazakhstan should be required to develop and disseminate typologies and methods of money laundering and financing of terrorism used in the region and internationally. Kazakhstan has developed a modern system of collecting and processing statistical data on pre-trial investigations. The same comprehensive system should be implemented for trial and post-trial procedures.

\section{International cooperation}

14. Kazakhstan is a party to the Vienna Convention and the International Convention on the Suppression of the Financing of Terrorism and a number of bilateral and multilateral treaties, which set forth a legal basis for the provision of various types of multilateral legal 
assistance. ${ }^{17}$ Kazakhstan has signed the Commonwealth of Independent States (CIS) Convention on Recognition of Legal Relations in Civil, Family and Criminal Matters (Chisenau Convention, 1993) and the 1999 CIS Treaty on Combating Terrorism. ${ }^{18}$ Despite these conventions, further expansion of legal mechanisms that would permit more liberal sharing of information and mutual cooperation in criminal matters should be considered. Chapter 55 of the Criminal Procedure Code requires adherence to letters rogatory procedures for legal assistance with respect to countries with which treaties have not been signed. This can be a cumbersome process, which causes substantial delays in the ability to cooperate with and provide mutual legal assistance to countries in an effective manner and where timeliness is critical.

15. Amendments to relevant laws, which would permit the bilateral Memoranda of Understanding Agreements that permit for broader and more efficient sharing of information concerning suspicious transaction activities and terrorist financing between FIUs, should be considered.

16. The AML/CFT Task Force currently is working on drafting an AML/CFT law, which would provide the legal basis for establishment of an FIU. The composition of this Task Force is, however, rather limited in nature and should be expanded to include appropriate representatives from all ministries and agencies, who will have responsibility for implementing the AML/CFT obligations under an AML/CFT law that meets international standards. Consideration should be given to including representatives from the Prosecutor's Office, Ministry of Interior, and Currency Control Department of the National Bank of Kazakhstan. In addition to drafting the AML/CFT law, the role of the Task Force should also be assigned to draft a national strategy and implementation program.

\section{Preventive measures for financial institutions}

\section{Prudentially regulated sectors}

17. As current secrecy provisions prevent the reporting of suspicious transaction activity to an authority for analysis and investigation, financial institutions can easily be used as mechanisms, in which criminal activity is protected and can thrive. The bank secrecy provisions of the Banking Law prevent the disclosure of any information concerning suspicious transactions to law enforcement officials or other bodies authorized to act on such information. As prevention and deterrence of money laundering or terrorist financing is not possible unless information on suspicious activities can be reported to appropriate authorities, reporting of suspicious transactions should be required by law. Provisions that impose civil or criminal liability for reporting suspicious transactions to authorities should be repealed, although penalties for unauthorized or inappropriate disclosure of such information should be

\footnotetext{
${ }^{17}$ Including treaties with China, Turkey, Lithuania, North Korea, South Korea, Iran, Czech Republic, Uzbekistan, Germany, and Italy.

18 The Chisenau Convention is expected to be ratified in 2004.
} 
available. Secrecy provisions that relate to other prudentially regulated sectors should be amended as necessary to allow for reporting suspicious transactions to authorized bodies without the risk of criminal or civil liability.

18. The AML/CFT law should require financial sector entities, relevant private sector entities and certain professionals to implement policies and procedures for identifying and reporting suspicious transactions to the FIU. Compliance with such reporting requirements should be regularly audited and appropriate penalties available for instances of noncompliance. Public sector officials should also be obligated to report suspicious transactions to the FIU. The FIU, together with law enforcement officials, should cooperate with the FSA and NBK to provide training and disseminate training materials to all professionals and legal entities obligated to report suspicious transactions, on identifying suspicious transactions (and typologies), on the legal obligations for reporting transactions, including penalties for non-reporting, and on mechanisms and forms for reporting.

19. Relevant laws and regulations should be amended to require all professionals and entities subject to AML/CFT obligations to classify all clients and customers into realistic risk categories, and implement know-your-customer documentation procedures, which realistically relate to the level of those risks. Such documentation should be sufficient to reasonably satisfy the service provider with reasonable certainty that the customer/client is legitimate and the funds transferred do not flow from illegitimate activities. In addition, service providers should be obligated to implement on-going monitoring procedures for all transaction activity such that suspicious transactions can be identified and reported. These requirements should be regularly audited by appropriate supervisory agencies, and instances of noncompliance should be penalized.

20. Relevant laws and regulations should be amended to require that all persons, entities, and service providers subject to AML/CFT law obligations maintain all customer account information and transaction documentation for a minimum of five years from the date of execution of the transaction. In addition, records on customer identification, account files, and business correspondence should be maintained for at least five years after the account is closed. These requirements should be regularly audited by appropriate supervisory agencies, and instances of noncompliance should be penalized. 


\section{Summary assessment against the FATF Recommendations}

Table 1. Recommended Action Plan to Improve Compliance with the FATF

\begin{tabular}{|c|c|}
\hline Reference FATF Recommendation & Recommended Action \\
\hline \multicolumn{2}{|l|}{40 Recommendations for $\mathrm{AML}$} \\
\hline $\begin{array}{l}\text { General framework of the Recommendations (FATF } \\
1-3)\end{array}$ & $\begin{array}{l}\text { - Sign, ratify and implement the UN Convention Against } \\
\text { Transnational Organized Crime (Palermo, 2001), and the } \\
\text { Council of Europe Convention on Laundering, Search, } \\
\text { Seizure and Confiscation of the Proceeds of Crime } \\
\text { (Strasbourg, 1990, ETS No. 141). } \\
\text { Amend relevant laws to fully implement the UN } \\
\text { Convention Against Illicit Traffic in Narcotic Drugs and } \\
\text { Psychotropic Substances (Vienna Convention, 1988), as } \\
\text { well as the UN Convention for the Suppression of the } \\
\text { Financing of Terrorism (1999). } \\
\text { Amend the bank secrecy provisions to permit the } \\
\text { reporting of suspicious transactions to law enforcement } \\
\text { authorities, which have authority to detect and prevent } \\
\text { money laundering and terrorist financing. }\end{array}$ \\
\hline $\begin{array}{l}\text { Scope of the criminal offense of money laundering } \\
\text { (FATF 4-6) }\end{array}$ & $\begin{array}{l}\text { - Amend relevant Criminal Code provision } 193 \text { to expand } \\
\text { the definition of money laundering to meet international } \\
\text { standards as set out in the international conventions, } \\
\text { ensuring that it can be prosecuted both separately and in } \\
\text { parallel with all predicate offenses and any offense which } \\
\text { generates illegal proceeds, including offenses involving } \\
\text { trade or smuggling of illegal drugs and weapons. } \\
\text { Train law enforcement and prosecutorial officials, as well } \\
\text { as judges to ensure a clear understanding of the amended } \\
\text { definition of money laundering, including that it can be } \\
\text { prosecuted as an offense that is separate or in parallel to } \\
\text { the crime which generates the illegal proceeds. }\end{array}$ \\
\hline Provisional measures and confiscation (FATF 7) & $\begin{array}{l}\text { - Improve legal mechanisms to allow the freezing or } \\
\text { seizure of property, proceeds and/or assets used or } \\
\text { intended for use in the financing of terrorism without } \\
\text { delay. } \\
\text { Make confiscation of criminal proceeds of money } \\
\text { laundering and terrorist financing matters mandatory so } \\
\text { that courts are obligated to consider the issue and to the } \\
\text { extent proceeds exist, confiscate them. } \\
\text { Enact a law fully implementing UN Security Resolutions } \\
\text { requiring mandatory review of names on terrorist lists } \\
\text { auditing of compliance processes, and penalties for } \\
\text { noncompliance obviating the need for a judge to } \\
\text { pronounce judgment regarding the terrorist status of } \\
\text { natural or legal persons. }\end{array}$ \\
\hline
\end{tabular}




\begin{tabular}{|c|c|}
\hline Reference FATF Recommendation & Recommended Action \\
\hline $\begin{array}{l}\text { General role of financial system in combating ML } \\
\text { (FATF 8-9) }\end{array}$ & $\begin{array}{l}\text { An AML/CFT law should legally obligate such reporting of } \\
\text { suspicious transactions and penalize noncompliance. Secrecy } \\
\text { provisions of the Banking Law and other financial secrecy } \\
\text { laws should be amended to allow entities/individuals subject } \\
\text { to AML/CFT reporting requirements to report suspicious } \\
\text { transactions to appropriate authorities without risk of civil or } \\
\text { criminal liability. }\end{array}$ \\
\hline $\begin{array}{l}\text { Customer identification and record-keeping rules } \\
\text { (FATF 10-13) }\end{array}$ & $\begin{array}{l}\text { The AML/CFT law should require relevant financial sector } \\
\text { and other appropriate entities to implement know-your- } \\
\text { customer policies and procedures to prevent such entities from } \\
\text { being used by criminals. The AML/CFT law should stipulate } \\
\text { that all transaction documentation should be maintained for a } \\
\text { period of five years, and that all records on customer } \\
\text { identification, account files, and business correspondence be } \\
\text { maintained for at least five years after the account is closed. }\end{array}$ \\
\hline $\begin{array}{l}\text { Increased diligence of financial institutions (FATF } \\
14-19)\end{array}$ & $\begin{array}{l}\text { The AML/CFT law should require on-going monitoring of } \\
\text { client transactions to detect any patterns of suspicious activity } \\
\text { with a view to reporting identified suspicious activity. } \\
\text { Monitoring procedures should be related to the risk } \\
\text { classifications of each category of clients/customers, with } \\
\text { higher risk categories subject to more frequent monitoring. } \\
\text { Other relevant laws and regulations should be amended to } \\
\text { ensure this obligation is applicable to all entities and } \\
\text { professionals obligated to report suspicious transactions } \\
\text { pursuant to the AML/CFT law. }\end{array}$ \\
\hline $\begin{array}{l}\text { Measures to cope with countries with insufficient } \\
\text { AML measures (FATF 20-21) }\end{array}$ & $\begin{array}{l}\text { AML/CFT policies and procedures should be applied to all } \\
\text { branches and subsidiaries subject to all AML/CFT obligations. } \\
\text { The AML/CFT law and other relevant laws and regulations } \\
\text { should require that entities and persons subject to AML/CFT } \\
\text { reporting obligations apply higher standards of due diligence } \\
\text { and transactions which involve jurisdictions that do not apply } \\
\text { FATF Recommendations. }\end{array}$ \\
\hline Other measures (FATF 22-25) & $\begin{array}{l}\text { Authorities should consider including in the AML/CFT law a } \\
\text { provision requiring reporting of all cash transactions above a } \\
\text { certain threshold limit. Authorities should also consider } \\
\text { stepping up procedures for monitoring of cross-border } \\
\text { transactions, particularly in view of the current process of } \\
\text { exchange control liberalization. }\end{array}$ \\
\hline
\end{tabular}




\begin{tabular}{|c|c|}
\hline Reference FATF Recommendation & Recommended Action \\
\hline $\begin{array}{l}\text { Implementation and role of regulatory and other } \\
\text { administrative authorities (FATF 26-29) }\end{array}$ & $\begin{array}{l}\text { The AML/CFT law (and relevant laws and regulations) should } \\
\text { require implementation of internal policies and procedures to } \\
\text { prevent and detect money laundering and terrorist financing } \\
\text { for all entities and professional service providers obligated to } \\
\text { report suspicious transactions pursuant to the AML/CFT law. } \\
\text { Appropriate supervisory authorities should regularly audit } \\
\text { compliance with obligations in the AML/CFT law, as well as } \\
\text { adherence to written internal AML/CFT policies and } \\
\text { procedures. Authorities should regularly disseminate updated } \\
\text { information to regulated entities concerning typologies of } \\
\text { money laundering and terrorist financing. Authorities should } \\
\text { be obligated to deny licenses to applicants, where supervisors } \\
\text { have reasonable grounds to suspect involvement in organized } \\
\text { crime, money laundering, terrorist financing, and/or terrorist } \\
\text { groups. }\end{array}$ \\
\hline $\begin{array}{l}\text { Administrative Cooperation - Exchange of general } \\
\text { information (FATF 30-31) }\end{array}$ & $\begin{array}{l}\text { Bilateral treaties with other countries, which permit the } \\
\text { straightforward sharing of information and mutual cooperation } \\
\text { in criminal matters, should be signed. Relevant amendments } \\
\text { to laws and regulations of financial sector supervisory } \\
\text { agencies should be made to permit the sharing of information } \\
\text { concerning suspicious transactions and customers with } \\
\text { counterpart agencies abroad. }\end{array}$ \\
\hline $\begin{array}{l}\text { Administrative Cooperation - Exchange of } \\
\text { information relating to suspicious transactions } \\
\text { (FATF 32) }\end{array}$ & $\begin{array}{l}\text { Relevant amendments to laws and regulations of financial } \\
\text { sector supervisory agencies should permit the sharing of } \\
\text { information concerning suspicious transactions and customers } \\
\text { with counterpart agencies abroad. Memoranda of } \\
\text { understanding agreements, which permit broad sharing of } \\
\text { information concerning suspicious transaction activities and } \\
\text { terrorist financing, should be signed between financial sector } \\
\text { supervisory bodies with counterpart agencies abroad, } \\
\text { including between the Kazakhstani FIU and foreign FIUs. }\end{array}$ \\
\hline $\begin{array}{l}\text { Other forms of cooperation - Basis and means of } \\
\text { cooperation in confiscation, mutual assistance, and } \\
\text { extradition (FATF 33-35) }\end{array}$ & $\begin{array}{l}\text { - Kazakhstan should consider additional provisions on mutual } \\
\text { assistance, which would allow it to give such assistance on a } \\
\text { case-by-case basis without the need for a bilateral or } \\
\text { multilateral treaty and without the need for the formalized } \\
\text { and lengthy letters rogatory process. } \\
\text { - Consider increasing the number of bilateral treaties, } \\
\text { particularly with countries which are generating a number } \\
\text { of requests, such as countries in Western Europe and North } \\
\text { America. } \\
\text { - Relevant international treaties on provision of mutual legal } \\
\text { assistance in criminal matters should be expediently signed } \\
\text { and implemented. }\end{array}$ \\
\hline $\begin{array}{l}\text { Other forms of cooperation - Focus of improved } \\
\text { mutual assistance on money laundering issues } \\
\text { (FATF 36-40) }\end{array}$ & $\begin{array}{l}\text { Modern investigative techniques should be permitted under } \\
\text { the Criminal Code to enable law enforcement authorities to } \\
\text { obtain evidence and investigate cross-border cases of money } \\
\text { laundering and terrorist financing, and so valuable mutual } \\
\text { legal assistance can be provided to requesting countries } \\
\text { expediently. }\end{array}$ \\
\hline
\end{tabular}




\begin{tabular}{|l|l|}
\hline \multicolumn{1}{|c|}{ Reference FATF Recommendation } & \multicolumn{1}{|c|}{ Recommended Action } \\
\hline $\begin{array}{l}\text { 8 Special recommendations on terrorist } \\
\text { financing }\end{array}$ & \\
\hline $\begin{array}{l}\text { I. Ratification and implementation of UN } \\
\text { Instruments }\end{array}$ & $\begin{array}{l}\text { Fully implement the UN Convention on the Suppression of the } \\
\text { Financing of Terrorism. }\end{array}$ \\
\hline $\begin{array}{l}\text { II. Criminalizing the financing of terrorism and } \\
\text { associated money laundering }\end{array}$ & $\begin{array}{l}\text { Amend the Criminal Code to make financing of terrorism a } \\
\text { separate criminal offense. }\end{array}$ \\
\hline III. Freezing and confiscating terrorist assets & $\begin{array}{l}\text { A legal mechanism should allow the freezing } \text { or seizure of } \\
\text { property, proceeds and/or assets used or intended for use in } \\
\text { the financing of terrorism. }\end{array}$ \\
\hline $\begin{array}{l}\text { IV. Reporting suspicious transactions related to } \\
\text { terrorism }\end{array}$ & $\begin{array}{l}\text { The envisaged AML/CFT law should require the reporting of } \\
\text { suspicious transactions to a FIU. }\end{array}$ \\
\hline V. International cooperation & $\begin{array}{l}\text { Appropriate supervisory agencies and law enforcement } \\
\text { officials should be legally permitted to provide information } \\
\text { upon request and mutual legal assistance to foreign } \\
\text { counterpart officials to support investigation and prosecution } \\
\text { of terrorists and groups financing terrorist activities. }\end{array}$ \\
\hline VI. Alternative remittance & $\begin{array}{l}\text { Authorities should give attention to the use of alternative } \\
\text { (informal) remittance systems, which operate outside the } \\
\text { formal financial sector, particularly with respect to the role } \\
\text { such might play in the financing of terrorism. }\end{array}$ \\
\hline VII. Wire transfers & $\begin{array}{l}\text { The AML/CFT law and other relevant laws and regulations } \\
\text { should require heightened attention to wire transfer payments, } \\
\text { particularly with respect to the use of wire transfers in terrorist } \\
\text { financing, particularly wire transfers without adequate } \\
\text { originator information. }\end{array}$ \\
\hline VIII. Nonprofit organizations & $\begin{array}{l}\text { Entities and professionals, which are obligated to report } \\
\text { suspicious transactions pursuant to the AML/CFT law, should } \\
\text { be required to pay particular attention to activities of nonprofit } \\
\text { organizations and any indications of suspicious activities or } \\
\text { transactions, particularly in regard to terrorist financing. }\end{array}$ \\
\hline
\end{tabular}

Table 2. Other Recommended Actions

\begin{tabular}{|l|l|}
\hline \multicolumn{1}{|c|}{ Reference } & \multicolumn{1}{c|}{ Recommended Action } \\
\hline Financial Intelligence Unit & $\begin{array}{l}\text { Create a Financial Intelligence Unit (FIU), which meets } \\
\text { international standards and is operationally independent, } \\
\text { adequately staffed, and supervised. }\end{array}$ \\
\hline
\end{tabular}

\section{Authorities' response}

24. The authorities concurred with the assessment. They expect that the practical implementation of the recommendations on amending the existing legal and institutional framework will become rather complex. 